\title{
Should everybody be in services? The effect of servitization on manufacturing firm performance
}

Matthieu Crozet \& Emmanuel Milet

\section{Highlights}

- In 2007, about $70 \%$ of the French manufacturing firms produced some services for third parties. This share is growing over time.

- These servitized firms are larger (in terms of total production and employment), produce more goods and are more profitable.

- There is a causal impact of servitization on firm performance: Firms that start selling services experience an increase in their profitability, employment, total sales and sales of goods.

- These positive effects of servitization strategies are mainly visible for small businesses. 


\section{Abstract}

The servitization of the manufacturing sector refers to the evolution of manufacturers' capabilities to offer services as a complement to or a substitute for the goods that they produce. A vast literature has described these strategies and has shown that this phenomenon is widespread and growing in most developed economies. However, very little systematic evidence of the extent or consequences of servitization based on a comprehensive dataset of firms exists. In this paper, we provide such evidence using exhaustive data for French manufacturing firms between 1997 and 2007. We find that the vast majority of French manufacturers sell services in addition to producing goods. The shift toward services is growing steadily but at a slow pace. We also provide evidence of a causal impact of servitization on firm performance. Controlling for various sources of endogeneity bias, we find that firms that start selling services experience an increase in their profitability between $3.7 \%$ and $5.3 \%$, increase their employment by $30 \%$, increase their total sales by $3.7 \%$, and increase their sales of goods by $3.6 \%$. The results hold for most industries, although some heterogeneity exists.

\section{Keywords}

Servitization,Deindustrialisation,Firm performance.

\section{JEL}

L23, L25, L6.

\section{Working Paper}

\section{CEPI}

CEPII (Centre d'Etudes Prospectives et d'Informations Internationales) is a French institute dedicated to producing independent, policyoriented economic research helpful to understand the international economic environment and challenges in the areas of trade policy, competitiveness, macroeconomics, international finance and growth.

CEPII Working Paper
Contributing to research in international
economics
(C) CEPII, PARIS, 2015
All rights reserved. Opinions expressed
in this publication are those of the
author(s) alone.

Editorial Director: Sébastien Jean

Production:

Laure Boivin

No ISSN: $1293-2574$
CEPII

113, rue de Grenelle

75007 Paris

+33153685500

www.cepii.fr Press contact: presse@cepii.fr 


\title{
Should everybody be in services? The effect of servitization on manufacturing firm performance
}

\author{
Matthieu Crozet* and Emmanuel Milet $^{\dagger}$
}

There are no such thing as service industries. There are only industries whose service components are greater or less than those of other industries.

Everybody is in services. Theodore Levitt (1972).

\section{Introduction}

The servitization of the manufacturing sector refers to the evolution of manufacturers capabilities to offer services, as a complement to or a substitute for the goods they produce. This trend is not recent and has been identified and documented since the 1980s (Vandermerwe and Rada, 1988). It is observed in all OECD countries and also in developing countries (Pilat et al., 2006; Neely et al., 2011). Examples of manufacturing firms selling services are numerous: from small businesses offering repair and after-sales services to Rolls Royce, which made "power by the hour" - a package of support services for aircraft engines - a core element of its strategy, ${ }^{1}$ or Apple, whose strategy is to offer to consumers an ecosystem combining physical devices with online services. ${ }^{2}$

The deeper integration of the production of goods and services is highly relevant for policymakers in high-income countries who worry about the decline of manufacturing production and employment in their economies. ${ }^{3}$ Economic analyses based on a representation of the economy as a collection of independent sectors often view the decline of the manufacturing sector as an ineluctable shift of resources toward the services sector (Baumol, 1967; Ngai and Pissarides, 2007; Acemoglu and Guerrieri, 2008). However, this representation as well as the ensuing industrial policies neglect the fact that the boundary between manufacturing and services is very blurry ${ }^{4}$ and that complementarity between services and manufacturing may be key to economic success.

\footnotetext{
*Univ Paris Sud, Universite Paris-Saclay and CEPI, (matthieu.crozet@cepii.fr)

†University of Geneva, (emmanuel.milet@unige.ch)

1 "Rolls-Royce earns its keep not just by making world-class engines, but by selling "power by the hour" - a complex of services and manufacturing that keeps its customers' engines burning. If it did not sell services, Rolls-Royce could not earn enough money from selling engines", The Economist (Jan. 8th, 2009).

${ }^{2}$ Between 2002 and 2010, Apple sold over 206 million iPods and over one billion songs through the iTunes Music Store (Benedettini et al., 2010).

${ }^{3} \mathrm{~A}$ recent report by the European Commission argues that European Commission (2014) "A digital transition is underway across the global economy and industrial policy needs to integrate new technological opportunities such as cloud computing, big data and data value chain developments, new industrial applications of internet, smart factories, robotics, 3-D printing and design."

${ }^{4} \mathrm{~A}$ fact underlined decades ago by Stigler (1956): "There exists no authoritative consensus on either the boundaries or the classification of the service industries." See Fuchs (1968) for an early discussion of the increasing importance of the services sector.
} 
Of course, the shift toward services has important consequences for firms; it affects their business models and how they approach consumers (Oliva and Kallenberg, 2003; Reinartz and Ulaga, 2008; Cusumano et al., 2015). This shift also provides a way to restore manufacturers' competitiveness in both local and global markets. ${ }^{5}$ Wise and Baumgartner (1999) argue that "Downstream [service] markets offer important benefits besides large new sources of revenue. They tend to have higher margins and to require fewer assets than product manufacturing. And because they tend to provide steady service-revenue streams, they're often countercyclical. Clearly, in manufacturing today, the real money lies downstream, not in the production function."

Previous studies of the consequences of servitization have identified various channels through which firms can benefit from this strategy. Servitization can enable firms to differentiate their product from those of their competitors (Baines et al., 2009), increase customer loyalty (Baines and Lightfoot, 2013), and lead to higher market values (Fang et al., 2008) or higher profitability (Neely, 2008; Suarez et al., 2013; Visnjic et al., 2014). However, little systematic and robust evidence of the impact of servitization on firm performance exists, and this question remains controversial. Prior research has shown that most of the expected benefits of servitization (higher revenues, higher profitability) does not materialize in many cases. ${ }^{6}$ Furthermore, most of the available empirical evidence is based on firm-level case studies or a limited sample of relatively large firms. These approaches have the advantage of allowing in-depth analysis of the business strategies and channels through which servitization operates. However, they lack the general validity that would allow inferences to be drawn from their results. Our paper is complementary to the existing literature in this regard. Our study is based on a comprehensive sample of firms, which covers all manufacturing sectors and naturally includes a large proportion of micro and small businesses. Our data contains detailed balance sheet information for more than 50,000 servitized and non-servitized French manufacturing firms over the 1997-2007 period. A key feature of our database is that it provides information on the sales (to third parties) of goods and services separately. This very large database allows the precise quantification of the evolution of the servitization of French manufacturing over the course of a decade; it also offers a means to estimate the causal impact of servitization on firm performance precisely, controlling for self-selection effects and other sources of endogeneity bias.

\footnotetext{
${ }^{5}$ Cusumano et al. (2015) distinguish between services that are offered as complements to the product sold by the firm and those that are substitutes. Within complementary services, they further distinguish between "smoothing services" whose purpose is to ease the purchase of the product (financing, insurance, basic training) and "adapting services" whose purpose is to alter the good to the specific needs of customers. While "smoothing services" can easily be standardized, "adapting services" are highly customized as "the knowledge required to provide the service is difficult to separate from detailed knowledge of the product itself". The "Power by the Hour" Rolls Royce product is an example of services that substitute for the purchase of the good. Customers buy the use of the engine rather than the engine itself, while Rolls Royce ensures that it is functional at any time.

"This "service paradox" is described by (Gebauer et al., 2005) as follows: "Most product manufacturers are confronted with the following phenomenon: Companies which invest heavily in extending their service business, increase their service offerings and incur higher costs, but this does not result in the expected correspondingly higher returns. Because of increasing costs and a lack of corresponding returns, the growth in service revenue fails to meet its intended objectives. We term this phenomenon the 'service paradox' in manufacturing companies." Visnjic et al. (2014) argue that the service paradox is likely to arise when firms move from "product-related" services to "customer-oriented" services.
} 
The empirical literature has typically found an ambiguous relationship between servitization and firm performance. Fang et al. (2008) use data on 477 publicly listed manufacturing companies and find a U-shaped relationship between the share of services of total sales and firm market value. Benedettini et al. (2013) analyze the characteristics of about 200 manufacturing firms from the manufacturing sector. After controlling for firm age and size, they find a negative correlation between the number of services offered by firms and their survival probability. Eggert et al. (2011) examine 414 German companies in the mechanical engineering industry and link product innovation and servitization to firm profitability. They find that when combined with product innovation, offering services supporting the product leads to higher profitability. Finally, the work closest to ours in terms of data and methodology is the analysis provided by Suarez et al. (2013). They look at the effect of servitization on operating profits using a sample of slightly fewer than 400 firms in the prepackaged software products industry and find a convex relationship between the share of services of total sales and overall operating margins. Their study covers a longer period than ours (1990-2006), but it is limited to one industry. We depart from several features of their analysis. First, we use a large sample of French firms that covers all manufacturing industries and allows us to assess how the impact of servitization varies by industry and type of firm. Second, we focus on the shift toward services rather than on the degree of servitization. Indeed, our results indicate that firm performance is mainly affected by the decision to engage in the provision of services rather than by their importance relative to total sales. Third, we look at several measures of performance: profitability, employment, total sales, and production sales of goods. This latter indicator of performance leads to us to discuss the complementarity or substitutability of goods and services. Fourth, thanks to the detailed nature of our data, we can implement a very precise micro-econometric estimation strategy, which addresses self-selection bias and reverse causality.

Finally, our contribution is twofold. First, we exploit our comprehensive database to document the extent of servitization in the French manufacturing sector. We show that in all French manufacturing industries, the share of services of total sales has increased substantially between 1997 and 2007. This increase is driven by two components: faster growth among servitized firms and a tendency for each firm to increase its share of services of total sales. Second, we assess the causal effect of engaging in services sales on firm performance. We explicitly tackle unobserved heterogeneity using a lagged dependent variable (LDV) model and reverse causality issues using instrumental variables. We find that firms that start selling services experience a significant boost in their profitability, ranging between $3.7 \%$ and $5.3 \%$. Their employment increases by $30 \%$, total sales by $3.7 \%$, and sales of goods by $3.6 \%$. These results hold for most industries, although some heterogeneity exists. Additionally, these results are primarily driven by small and medium enterprises, while the estimation for a sample of large firms produces less significant results.

In the next section, we describe the dataset. We then describe the change in servitization in French manufacturing industries in section 3. In section 4, we present our empirical strategy and our results. We conclude in section 5 . 


\section{Data}

We use firm-level information from the BRN (Bénéfice Réels Normaux) database. The database is compiled by the French fiscal authority (Direction Générale des Impôts) and provides firm information such as employment, value added, capital stock, profits, investments, industry classification, and geographic location. Of particular interest for this paper, the BRN dataset reports detailed information on firm sales. Individual sales are split into three mutually exclusive categories: sales of production of goods, sales of production of services and sales of merchandise (goods purchased and sold without transformation). Note that these are sales to third parties, i.e., to consumers outside of the firm. ${ }^{7}$ It is important to note that in this paper, we are interested in the servitization of French manufacturing firms, i.e., in the fact that manufacturing firms sell services to third parties. We are not interested in the production of services for own accounts. ${ }^{8}$ Our data cover the 1997-2007 period. The raw dataset provides information on 67,385 manufacturing firms. The average firm employs 55 workers and generates a turnover of $€ 12$ million.

This dataset is very large, but individual data are noisy and sometimes report values that we consider highly dubious. For instance, some firms change their industry classification every year, moving from one 2-digit sector to another. This complicates the design of an appropriate control group, as we want to compare firms operating in the same industry. The dataset also contains information on firms that report no production, no value added, or no employment. To cope with these issues, we trim the data based on several factors. First, we keep firms reporting strictly positive sales, employment or value added. This step reduces the size of the dataset quite substantially. Second, we select those firms whose capital to labor ratio and value added per worker are not greater than a hundred times the median ratio in their industry. ${ }^{9}$ We are left with 50,530 manufacturing firms. In this sample, the average firm employs 60 workers and has total sales of approximately $€ 13$ million.

In our sample of manufacturing firms, $76 \%$ report selling some services. These firms account for approximately $90 \%$ of the total value added and employment in our sample. Among the firms that report positive sales of services, $22 \%$ report more sales of services than sales of (produced) goods, and 12\% report only selling services. There are several explanations for these two somewhat surprising facts. Some firms may be misclassified and registered as manufacturing firms although their main activity is services. Other firms may have given up the production of goods to focus on the provision of services while still selling goods that they buy from other firms. It is important to note that French

\footnotetext{
${ }^{7}$ The dataset does not provide information on the type of service sold by firms. Services and product sales are indistinctly exports or domestic sales. Note that for firms that belong to a group, they can be sales to other affiliates or to subsidiaries of the group.

${ }^{8}$ Lodefalk (2013) considers the purchase and the production of services in Swedish manufacturing firms over the 1975-2005 period.

${ }^{9}$ Firms report such extreme values of these ratios for two reasons. The first obvious reason is misreporting; the second is related to how firms manage their capital. Consider the following example: For tax purposes, a firm may decide to create an entity whose only purpose is to own its real estate assets. In this setting, the first firm is producing goods and employing workers but appears to have little or no capital. The second firm, which is entirely linked to the first, has a (potentially large) capital stock with few (if any) workers. Depending on how the boundaries of the firms are defined, we are left with two apparently distinct entities, both with capital to labor ratios that do not actually reflect the activities of the firm.
} 
firms are not automatically reclassified when their main activity changes partly because collective labor agreements are defined at the sector level, which can make reclassification costly and cumbersome for both employers and employees. To better describe this dual activity of French manufacturing firms, we define the service intensity of a firm as the share of services of total production sales. The service intensity ranges from 0 (pure goods producers) to 1 (pure services producers). In figure 1 , we present the kernel distribution of service intensity (on a log scale) for the manufacturing firms in our sample in 1997 and 2007. The striking feature of this distribution is its bi-modality. This feature is present in both years and is observed in each manufacturing industry (see figure 2). ${ }^{10}$

Most of manufacturing firms are mainly goods producers (they produce and sell more goods than services). In 2007, firms with a service intensity below 50\% accounted for $84 \%$ of the firms in our sample and for $90 \%$ of both value added and employment. Figure 1 also reveals that the distribution remained quite stable between 1997 and 2007.

Figure 1 - Distribution of the Service Intensity (share of services of production sales) for French Manufacturing Firms in 2007

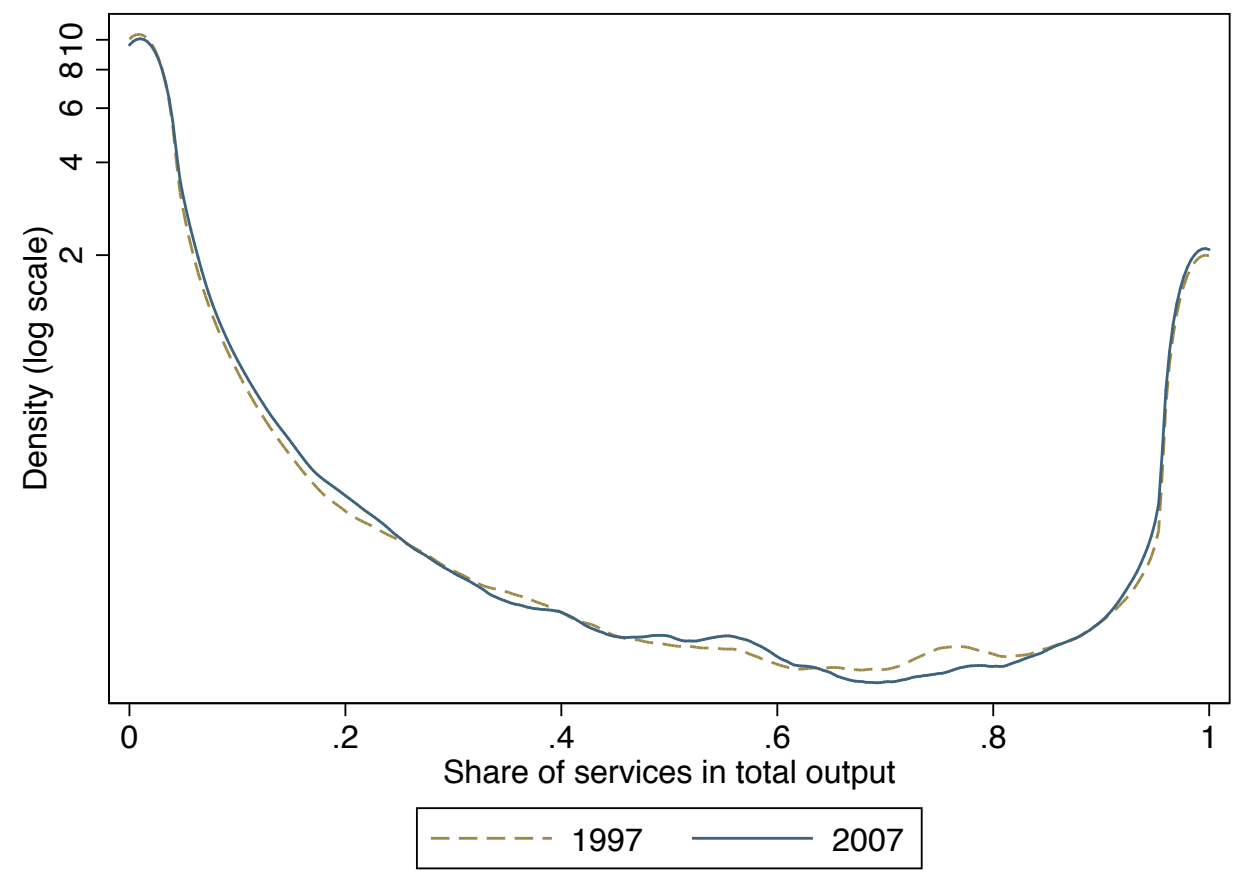

To dig deeper into the changes in the distribution of service intensity over time, we computed a transition matrix between 1997 and 2007 (see table 8 in the appendix). In this table, we retained a constant sample of firms and allocated them to bins based on their initial service intensity in 1997 and their service intensity in 2007. To understand how to interpret the figures reported in the table, let us consider the first row of the table: We find the share of firms that had a service intensity of exactly $0 \%$ in 1997 . Adding all shares reported in this row, the table indicates that this was the case for $22 \%$ of the firms in our sample. By 2007 , a majority of these firms (11.98\% of the total sample) remained fully

\footnotetext{
${ }^{10}$ Our database covers 21 2-digit industries. In the econometric analyses presented in sections 3 and 4, we systematically control for 2-digit industry fixed effects. However, to facilitate the exposition, we group the 2-digit industries into 7 broad categories.
} 
Figure 2 - Distribution of the Service Intensity by Industry in 2007

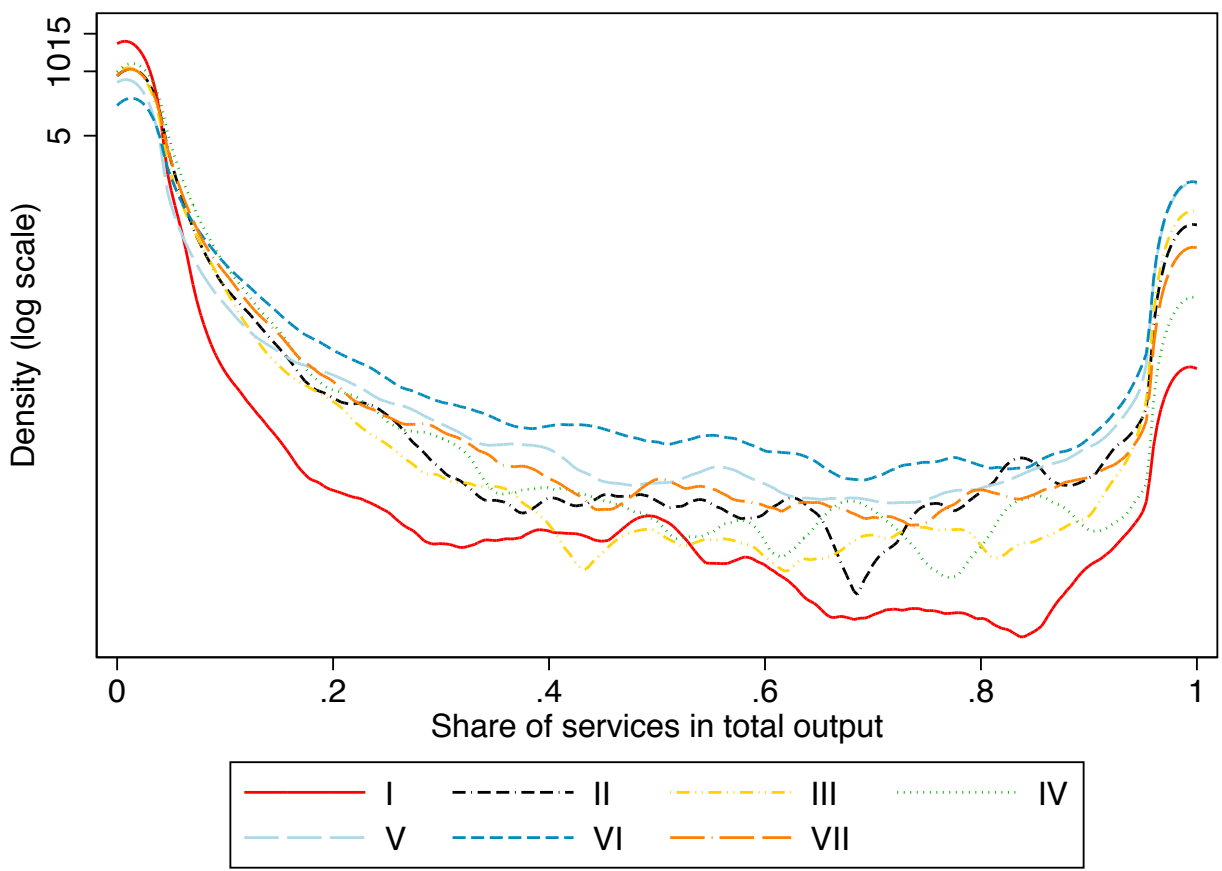

We grouped industries into large sectors using the NACE-Rev1 industry classification (indicated in parentheses). I: Manufacture of food products, beverages and tobacco $(15,16)$. II: Manufacture of textiles and leather products $(17,18,19)$. III: Manufacture of wood and wood products; manufacture of pulp, paper and paper products; publishing and printing $(20,21,22)$. IV: Manufacture of chemicals, chemical products and man-made fibers; manufacture of rubber and plastic products $(24,25)$. V: Manufacture of other non-metallic mineral products, basic metals and fabricated metal products $(26,27)$. VI: Manufacture of machinery, electrical, optical and transport equipment $(29,30,31,31,33,34,35)$. VII: Manufacturing, n.e.c. We omitted firms in the manufacture of coke, refined petroleum products and nuclear fuel industry (23), as only 4 firms existed in 2007.

specialized in the production of goods, while the rest (about $10 \%$ of the total sample) were selling some services in 2007 . Among the latter, a vast majority $(7.42 \%$ of the sample) had sales of services that accounted for less than $10 \%$ of their total production sales. This is a salient feature of the matrix: Most firms do not change their production mix much. Approximately $60 \%$ of firms lie on the diagonal of the table. Only $23 \%$ of firms are located strictly above the diagonal, meaning that they substantially increased their service intensity between 1997 and 2007, and only 17\% of the firms decreased their service intensity. Finally, very few firms completely changed their production mix during this period: Only 3.5\% of the firms moved from a low service intensity in 1997 (below $10 \%)$ to more than $90 \%$ of services in $2007(0.25+1.30+0.42+1.57=3.54)$.

Together, figures 1 and 2 and table 8 convey the following message. We encounter two distinct types of firms in the French manufacturing sector: Firms that are mainly goods producers (with a service intensity below 50\%) and those that are specialized in the provision of services. The distribution of these two types of firms is quite stable over time, and very few firms move from one type to another. As the focus of this paper is the production of services by manufacturers, we consider firms that are mainly good producers (i.e., those that have always a service intensity below 50\%). All firms that sell 
more services than goods in at least one year are excluded from our sample. This leaves us with a sample of 39,814 manufacturing firms, which remains quite similar to the raw dataset. In this sample of goods producers, the average firm employs 66 workers and generates $€ 14$ million in total sales. The average firm in this sample is slightly larger than in the raw dataset, although the difference is not statistically different. It is important to notice that excluding firms with a share of services above $50 \%$ has no consequences for our econometric analysis of the impact of servitization presented in section 4 . As our identification strategy relies on firms switching from zero to positive sales of services, firms with a service intensity above 50\% typically provide services every single year in our sample and thus do not contribute to the identification process.

\section{The servitization of French manufacturers}

This section gives an overview of the degree of servitization of French manufacturing over the decade from 1997 to 2007.

Table 1 - Summary Statistics

\begin{tabular}{|c|c|c|c|c|c|c|c|}
\hline & \multicolumn{3}{|c|}{ All firms } & \multicolumn{3}{|c|}{ Servitized firms } \\
\hline & & 1997 & 2007 & $\Delta 97-07$ & 1997 & 2007 & $\Delta 97-07$ \\
\hline \multirow[t]{2}{*}{ (1) } & \# Firms & 25,660 & 22,675 & -1.23 & 17,826 & 15,740 & -1.24 \\
\hline & Share (\%) & & & & 69.4 & 69.4 & \\
\hline \multirow[t]{4}{*}{ (2) } & Employment & & & & & & \\
\hline & Total (thousand) & 1,661 & 1,417 & -1.58 & 1,443 & 1,274 & -1.23 \\
\hline & Share $(\%)$ & & & & 86.9 & 89.9 & \\
\hline & Average & 64.7 & 62.5 & -0.35 & 80.9 & 81.0 & +0.0 \\
\hline \multirow[t]{4}{*}{ (3) } & Turnover & & & & & & \\
\hline & Total (€, million) & 294.3 & 378.0 & +2.53 & 261.0 & 350.2 & +2.99 \\
\hline & Share $(\%)$ & & & & 88.7 & 92.6 & \\
\hline & Average $(€$, thousand) & 11.5 & 16.7 & +3.81 & 14.6 & 22.3 & +4.27 \\
\hline \multirow[t]{4}{*}{ (4) } & Production of goods & & & & & & \\
\hline & Total (€, million) & 261.4 & 325.2 & +2.21 & 229.0 & 298.0 & +2.67 \\
\hline & Share $(\%)$ & & & & 87.6 & 91.6 & \\
\hline & Average $(€$, thousand) & 10.2 & 14.3 & +3.48 & 12.8 & 18.9 & +3.95 \\
\hline \multirow[t]{2}{*}{ (5) } & Profitability & & & & & & \\
\hline & Average $(\%)$ & 47.44 & 49.0 & +0.31 & 48.4 & 50.5 & +0.42 \\
\hline \multirow[t]{4}{*}{ (6) } & Service intensity & & & & & & \\
\hline & Average $(\%)$ & 3.1 & 3.2 & +0.33 & 4.5 & 4.6 & +0.34 \\
\hline & Median (\%) & 0.5 & 0.6 & +2.47 & 1.4 & 1.6 & +1.76 \\
\hline & Std. dev. & 0.07 & 0.07 & & 0.08 & 0.08 & \\
\hline
\end{tabular}

$\Delta 97-07$ corresponds to the annualized growth rate between 1997 and 2007. The sample is firms producing mainly goods (i.e., whose service intensity is below $50 \%$ over the period). Servitized firms report strictly positive sales of services.

In table 1, we present some descriptive statistics for the population of servitized and non-servitized French manufacturing firms in our sample. ${ }^{11}$ In the left part of the table,

\footnotetext{
${ }^{11}$ All these figures are computed from the sample of firms that are mostly producers of goods (i.e., those
} 
we show statistics for servitized and non-servitized firms, and we restrict the sample to servitized producers in the right part of the table. The first line illustrates the rapid deindustrialization of French economy. Between 1997 and 2007, the number of firms in our sample decreased by almost $12 \%$ (equivalent to an annual growth rate of $-1.23 \%$ ), and the number of workers employed in our sample of manufacturing firms decreased by $14.7 \%(-1.58 \%$ per year). Table 1 also shows that servitized firms are, on average, larger than pure manufacturers. In 2007, they employed 81 workers, on average, compared to 62.5 for pure manufacturers. Servitized firms are also larger in terms of turnover, they produce and sell more goods, and they are more profitable. All these differences will be studied in detail in the next section.

Figure 3 better illustrates the extent of servitization across manufacturing industries, using three different indicators. Panel (a) shows the proportion of manufacturing firms that produce services in 1997 and in 2007 . It confirms that servitization is a quite common strategy among French manufacturing firms: Almost $70 \%$ of the firms in our sample produce some services for third parties. This figure varies substantially by sector, ranging from $54 \%$ in the food, beverage and tobacco industry to $88 \%$ in the chemical and plastic products industry. The share of servitized firms has increased in every industry between 1997 and 2007, with the exception of the wood, paper and printing industry. While a very large majority of firms are servitized in all industries, most of them sell very few services. This pattern is visible in panel (b), which displays the average service intensity in each industry. In 2007, the service intensity is equal to $3.2 \%$ for the manufacturing sector as a whole. Again, there is some heterogeneity across manufacturing industries. For the average firm in the food, beverage and tobacco industry, services account for $1.3 \%$ of production sales, while they account for $5 \%$ in the mechanical and electrical equipment industry (which here includes optical and transport equipment). ${ }^{12}$ Finally, panel (c) shows the importance of services to the total production of manufacturing industries. It reports the average service intensity weighted by the production of each firm. These figures are, on average, larger than those in panel (b), suggesting that larger firms have on average higher levels of service intensity. In 2007, services accounted for $5.5 \%$ of the total production sales of the manufacturing sector compared to $4.2 \%$ in 1997 . Services accounted for around $2.5 \%$ of total production sales in the food, beverage and tobacco industry and up to $8.1 \%$ of production sales in the mechanical and electrical equipment industry in 2007.

This measure of the scope of servitization shows a steady rise over the decade, as shown in figure 4. The figure displays the evolution of the weighted average service intensity between 1997 and 2007 along with the share of employment at servitized firms. We take 1997 as the reference year, so the vertical axis can be read as growth rates. The weighted average service intensity was 30\% larger in 2007 than in 1997, and the share of employment at servitized firms grew by an average of $0.3 \%$ per year over the period.

with a service intensity below 50\%). Table 7 in the appendix displays exactly the same statistics computed from the complete sample of firms.

${ }^{12}$ Logically, retaining the (relatively few) firms that produce more services than goods in the sample greatly changes the average level of service intensity but does not affect the median value much. For 2007, table 7 in the appendix reports an average service intensity of $23.1 \%$ and a median of $3.2 \%$. 


\section{Figure 3 - The Extent of Servitization in French Manufacturing Industries}

(a) Share of servitized firms

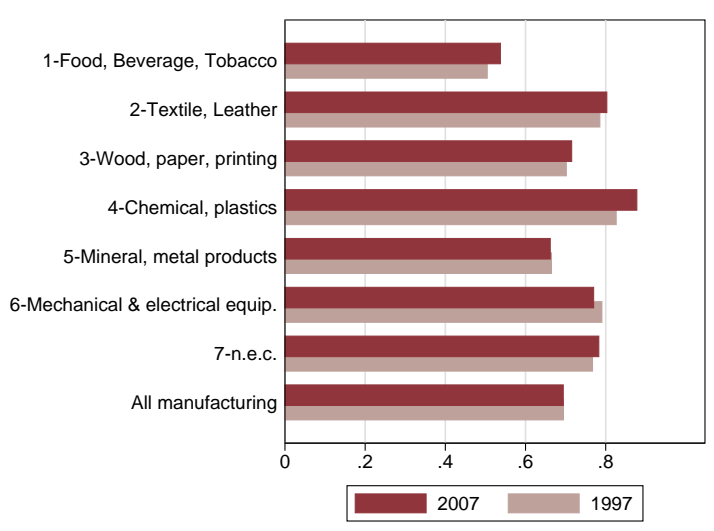

(b) Average service intensity (unweighted)

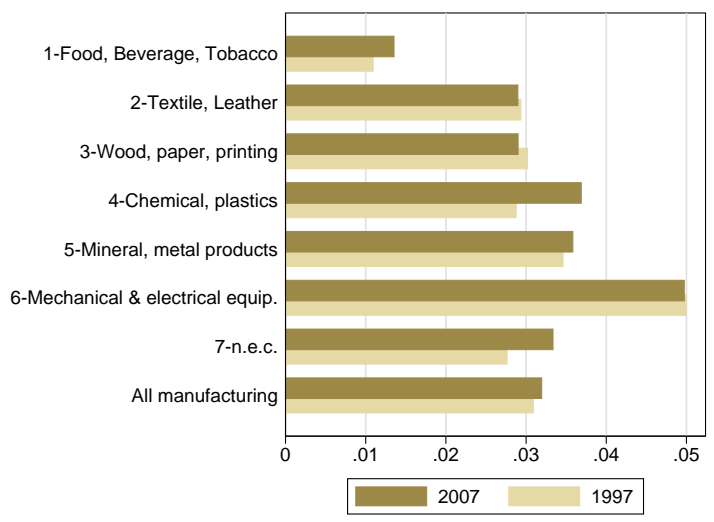

(c) Share of services in industry production

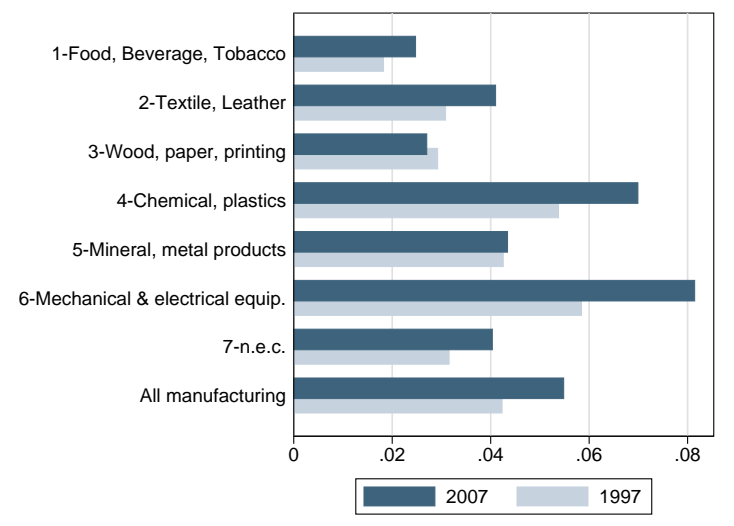

Figure 4 - Aggregate Servitization and Employment: 1997-2007

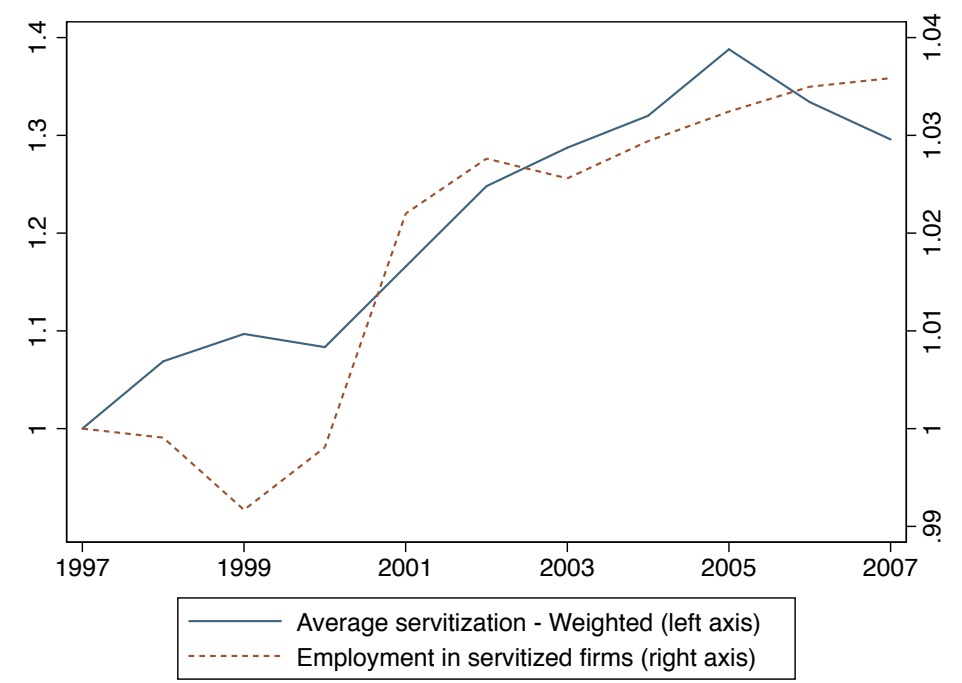


The global trend toward services shown in figure 4 contains two potential sources of change: a generalized shift toward services in individual firms and a composition effect due to the fact that firms with a high service intensity may grow faster than other firms. We isolate the first source of variation by estimating the following equation:

$$
\text { Service Intensity }{ }_{i t}=\beta_{i}+\delta_{t}+\epsilon_{i t} \text {, }
$$

where Service Intensity Is $_{i t}$ is the share of services of total sales of firm $i$ at time $t ; \beta_{i}$, which controls for any firm characteristic constant over time, is a firm fixed effect; $\delta_{t}$ is a set of year dummies; and $\epsilon_{i t}$ is the error term. We omit the dummy for the year 1997 so that the estimated coefficients on the dummies $\delta_{t}$ measure the yearly average change in service intensity within each firm with respect to 1997 . We display the results graphically in figure 5 where we plot the coefficients on each $\delta_{t}$ along with a 95\% confidence interval. A positive (and statistically significant) coefficient means that, on average, firms have increased their service intensity with respect to their initial level in 1997 . The dashed line represents an estimation with simple OLS, while the solid line shows the estimates obtained from a linear regression wherein observations have been weighted by the average employment of the firm over the period. All the coefficients are positive and statistically significant and increase over time. This means that the growing importance of services in the total production of manufacturing firms is not entirely driven by faster relative growth among servitized firms. On the contrary, each firm has increased its service intensity between 1997 and 2007 by an average of 1.5 percentage points. In 1997, the (weighted) average service intensity was $4.2 \%$. An average increase of 1.5 percentage points in each firm represents an average increase of 35\% over the decade (or 3\% per year).

Figure 5 - Firm-level Servitization: 1997-2007

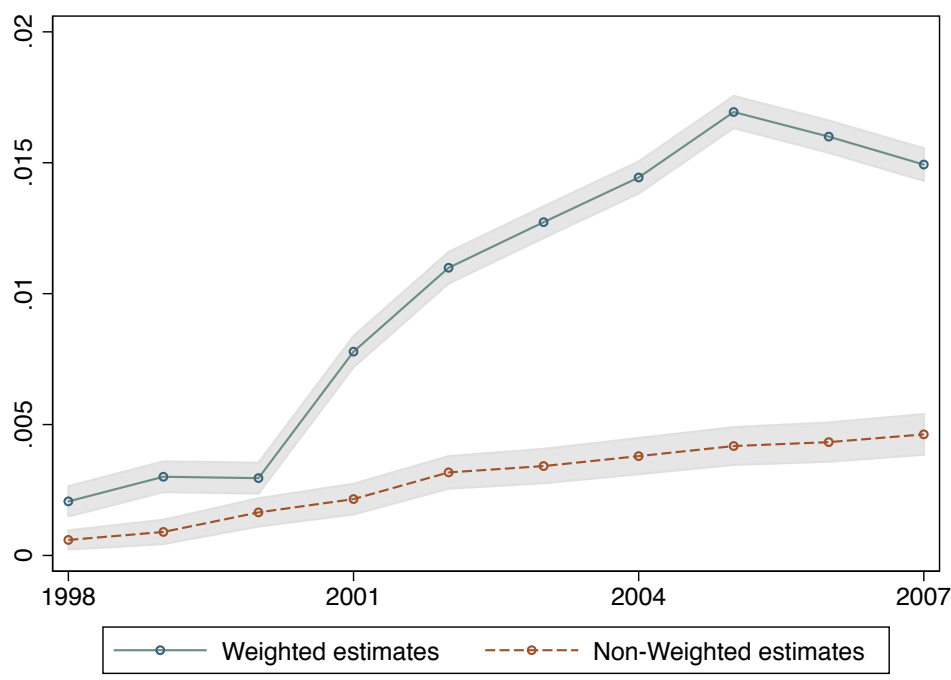

\section{The impact of servitization on manufacturing firm performance}

In this section, we analyze the interaction between servitization and firm performance. The following two subsections address two questions: Do servitized firms outperform pure manufacturers, and do firms that shift toward services improve their performance? 
We retain four indicators of performance: profitability (which we proxy by EBITDA Earnings Before Interest, Taxes, Depreciation, and Amortization - divided by value added), employment, turnover, and the production sales of goods. ${ }^{13}$

\subsection{Servitization premia}

Before we estimate the causal impact of servitization on performance, we provide evidence of the magnitude of the performance gap between servitized and non-servitized firms. To assess the differences between the two groups of firms precisely, we have to remove possible composition effects and compare firms in the same year and industry. This is accomplished by estimating the following equation:

$$
\text { Performance }_{i, t}=\sum_{k=0}^{k=49} \theta_{] k ; k+1]} d_{] k ; k+1], i, t-1}+\text { Employment }_{i, t-1}+\delta_{j, t}+\epsilon_{i, t} \text {, }
$$

where Performance $e_{i, t}$ is a variable characterizing the performance of firm $i$ in year $t$ : firm i's profitability (as a percentage), (log) employment, (log) turnover, and (log) sales of goods at time $t . \delta_{j, t}$ is a 2-digit industry $\times$ year dummy, and $\epsilon_{i, t}$ is the error term. The dummies $d_{j k ; k+1], i, t-1}$ are defined as follows:

$$
d_{j k, k+1], i, t-1}= \begin{cases}1 & \text { if } k<\text { Service Intensity } \\ 0 & \text { otherwise }\end{cases}
$$

Each of the 50 dummy variables $d_{j k ; k+1], i, t-1}$ takes the value 1 if the service intensity of firm $i$ lies in the interval ] $k ; k+1$ ], where $k$ varies from $0 \%$ to $49 \%$. The coefficients $\theta_{] k ; k+1]}$ on these dummies are estimated, taking the performance of non-servitized firms as a reference. They are interpreted as the average performance gap (i.e., the "premium") between pure manufacturers and firms with a given service intensity within the same year and industry. Because profitability, turnover, and total sales of goods are likely to be correlated with firm size, we control for lagged employment in those regressions. ${ }^{14}$

The results are presented in figures 6 and 7 . We graphically report only the coefficients $\theta_{j k ; k+1]}$ along with the $95 \%$ confidence interval. Dark/plain circles represent significant coefficients while light/hollow circles represent coefficients that are not statistically different from zero at the $95 \%$ level. It is noteworthy that around $87 \%$ of servitized firms in our sample are included in the first ten dummies (i.e., services account for less than $10 \%$ of their production sales). In figure 6 , we display the profitability premia of being servitized firms. These premia are positive and statistically significant, and they are remarkably stable over the range of service intensities. Regardless of the service intensity, servitized firms exhibit greater profitability of 3.5 percentage points with respect to non-servitized firms of comparable size in their industry. In 2007, the median profit rate was $46 \%$. An increase of 3.5 percentage points is equivalent to a $7.6 \%$ increase. The coefficients $\theta_{j: k+1]}$

\footnotetext{
${ }^{13}$ We do not consider sales of products that are bought and sold without transformation by the firm. See Bernard and Fort (2013) on a description of "factoryless goods producers", i.e. firms who do not produce themselves the goods they sell, but are involved in the design and coordinate their production.

${ }^{14}$ The premia are very similar when we do not control for employment.
} 
become non-significant for firms with service intensities greater than $30 \%$. Very few firms have a service intensity above $30 \%$ in our sample, which may explain the non-significance of these coefficients.

Panel (a) of figure 7 shows the premia in terms of employment. The estimated coefficients $\theta_{] k ; k+1]}$ are all positive and statistically significant. Their magnitude decreases with service intensity, but they remain positive. In panel (b), we show how (the log of) turnover of servitized firms compares with that of pure manufacturers. The results appear similar to those in panel (a). For service intensities below 30\%, the premia are significant, positive, and stable. For high levels of service intensity, the premia seem small, but the small number of firms in these categories sharply reduces the precision of the estimates. On average, servitized firms with a service intensity below 30\% generate almost 20\% more revenue than do non-servitized firms. In panel (c), we consider the sales of goods. The estimated coefficients $\theta_{] k ; k+1]}$ are positive and significant for low levels of service intensity. They become negative and statistically significant once the service intensity is greater than $20 \%$. The positive and significant coefficients reveal that firms selling few services have larger sales of goods than firms that do not sell services at all. On average, firms with a service intensity below $10 \%$ sell $16 \%$ more goods than pure goods producers. Recall that most of the servitized firms in our sample $(87 \%)$ have service intensity below $10 \%$. The negative coefficients on $\theta_{j k ; k+1]}$ when the service intensity is greater than $20 \%$ therefore concern very few firms. These results indicate a dual relationship between the production of services and the production of goods, which can be complements or substitutes. On the one hand, the provision of services is complementary to the production of goods when services represent a very small proportion of total firm production. On the other hand, some firms tend to specialize in the production of services, increasing their provision of services in lieu of goods production. 
Figure 6 - Relative Profitability of Servitized Firms

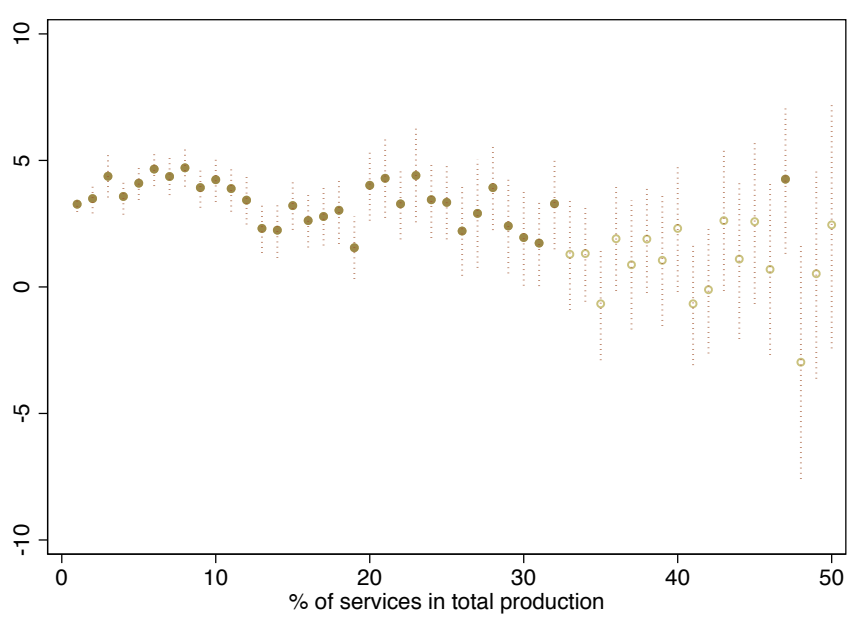

Figure 7 - Relative Performance of Servitized Firms (employment, turnover, and production of goods)

(a) Employment (log)

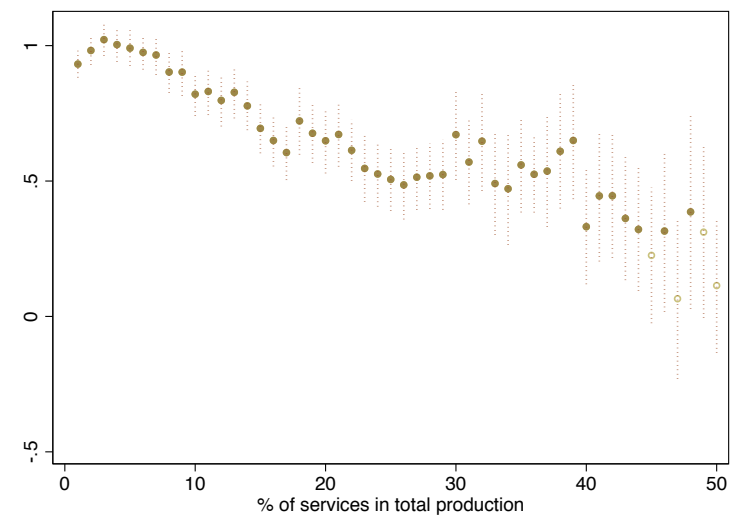

(b) Turnover $(\log )$

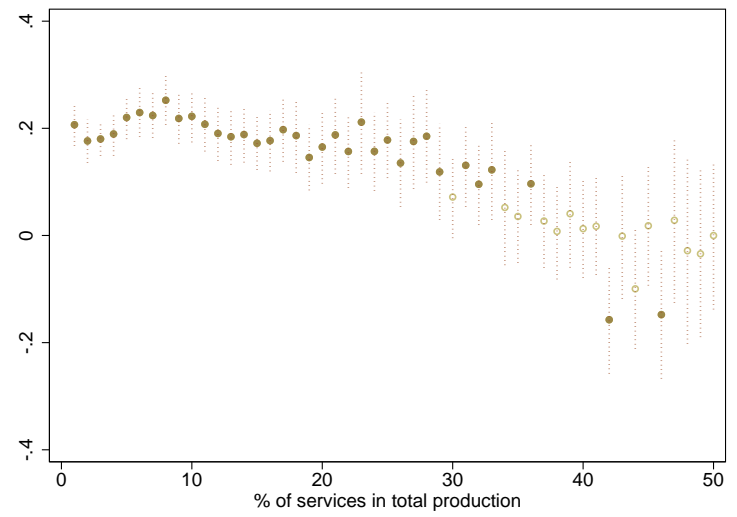

(c) Sales of goods (log)

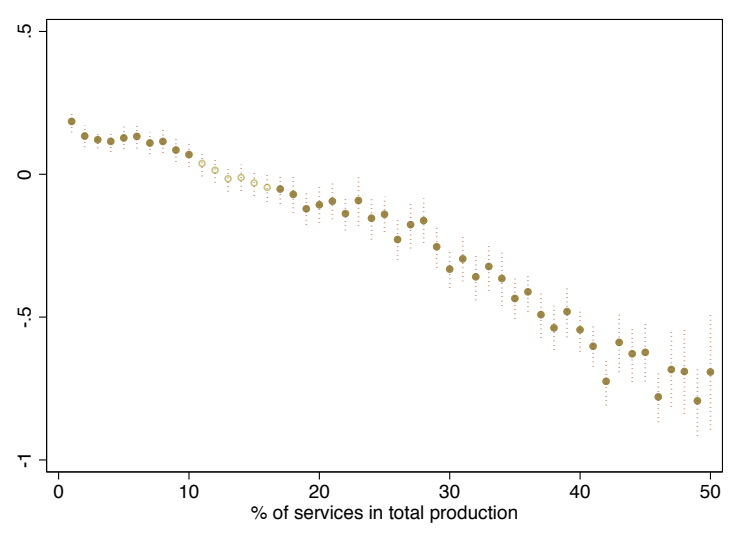




\subsection{The causal impact of servitization: empirical strategy}

The premia reported in figure 7 deliver two key messages. First, servitized firms have better performance than non-servitized firms: They are larger (in terms of employment and production) and more profitable. Second, with the exception of the production of goods, service intensity does not influence the premia much. Selling services is associated with better performance, even when they represent a very small share of firm sales. The premia do not increase with the share of services of total output. Together these results suggest that the decision to start selling services is what really matters, while the decision to sell more or fewer services does not seem to correlate with firm performance. Building on this observation, our causal analysis will focus on the decision to start selling services rather than on changes in the service intensity. ${ }^{15}$

The premia shown above are simple OLS estimates and suffer from patent endogeneity problems. Our first concern is that some confounding factors could be simultaneously correlated with both the decision to start selling services and firm performance. The decision to start selling services may be motivated or influenced by changes in firm environments (e.g., changes in competition pressure, technological changes, evolution of public regulations, improvement of transport and telecommunication infrastructures). The decision may also depend on unobserved firm-level characteristics, such as manager ability and past experiences. Failing to control for these confounding factors can seriously bias estimates.

The second concern is reverse causality induced by self-selection. Do firms decide to sell services because they have good performance or do they have better performance because they also sell services to their consumers? The bias may occur in both directions. On the one hand, servitization may be a selective process whereby only the highest-performing firms find it profitable to sell services. This mechanism will be observed, for instance, if firms have to invest in and allocate some managerial resources to start selling services. These investments may not be affordable to firms with low profits or strong financial constraints. They may also be non-profitable for firms with low competitiveness because the potential commercial gain they expect from selling services may not compensate for the fixed investment cost. In this case, the OLS estimates would be biased upward. On the other hand, a negative relationship between ex ante firm performance and the decision to start selling services may also exist. When facing a negative shock, firms may try to restore their market shares and profits by shifting their production toward services in order to generate additional revenues and/or to add value to the good they sell. If the decision to start selling services is a defensive strategy for declining firms, we would expect the OLS estimates to be biased downward. ${ }^{16}$

Our response to these endogeneity problems is twofold. First, we control for unobserved confounding factors that may simultaneously influence the decision to sell services and firm performance. The traditional method to address unobserved variables is to use firm-

\footnotetext{
${ }^{15}$ In unreported regressions, we also examined how changes in the share of services of total sales affect firm performance. The estimations produced volatile and non-robust results, which confirms the ambiguous impact of service intensity on firm profitability shown by Suarez et al. (2013).

${ }^{16}$ Breinlich et al. (2014) provide empirical evidence in favor of such a defensive strategy. They show that increasing competition pressure resulting from lower European manufacturing tariffs caused British firms to shift into the provision of services and out of the production of goods.
} 
level fixed effects in a difference-in-differences approach. This is not the most appropriate method in our case. Difference-in-differences estimators are based on the assumption that the most relevant unobserved confounders are time-invariant, which may not be true here. It is very likely that firms that decide to sell services have recently experienced some specific shock: a negative shock that reduced their profitability, a positive shock that provided them the resources needed to invest in a new activity, or simply a change in their management team or ownership structure that may influence their strategies and performance in some undetermined way. ${ }^{17}$ In this case, the most appropriate econometric strategy is to estimate an LDV model in which all relevant omitted variables (including those that are time varying) are controlled for by the lags of the dependent variable. Compared to a fixed effects model, an LDV model offers better control for self-selection and the ensuing reverse causality bias. ${ }^{18}$ In addition, we introduce year $\times$ industry fixed effects to capture unobserved determinants that may influence performance in a given year and 2-digit industry (e.g., changes in technology, regulations, infrastructures, competitive environment). Our preferred specification is:

$$
\text { Performance }_{i, t}=\alpha \mathbb{1}\left(\operatorname{serv}_{i, t-1}\right)+\sum_{k=1}^{\# \text { Lags }} \gamma_{k} \text { Performance }_{i, t-k}+\chi_{i, t-1}+\delta_{j, t}+\mu_{i, t}
$$

where Performance ${ }_{i, t}$ measures the performance of firm $i$ in year $t$ (i.e., profitability, employment, turnover, or production of goods); $\mathbb{1}\left(\operatorname{ser} v_{i, t-1}\right)$ is a dummy variable taking the value one if the firm $i$ sells services at $t-1$ and zero otherwise; $\chi_{i, t-1}$ is a vector of control variables, which are all lagged by one period to avoid simultaneity issues; $\delta_{j, t}$ is a set of year $\times 2$-digit industry fixed effects; and $\mu_{i, t}$ is the error term. As the accuracy of the parameter estimates tends to increase with the number of lags of the dependent variable (Wilkins, 2015), our preferred specification includes three lags (i.e., \#Lags = 3 in equation (3)). ${ }^{19}$ The coefficient of interest, $\alpha$, measures the average treatment effect (ATE), i.e., the observed impact of sales of services on Performance $e_{i, t}$.

The LDV model, by explicitly controlling for the trend of past firm-level performance, addresses the omitted variables issue and helps alleviate concerns about reverse causality bias. Nevertheless, reverse causality bias may persist if firms start selling services because they anticipate changes in their performance. For instance, firms innovating in products

\footnotetext{
${ }^{17}$ The literature has emphasized the role of organizational changes in successful transitions to services. When moving toward services, firms often need to change their organizational structures and business models. These changes are costly, and firms may fail to implement them successfully, thus leading to the previously described"service paradox." Bowen et al. (1989) argue that managers in manufacturing companies are often reluctant to adopt service-specific values, as these values contradict traditional manufacturing goals and practices, such as standardization and efficiency. This point is also made by Gebauer and Fleisch (2007), who argue that "managers are highly risk-averse when it comes to replacing their traditional productoriented values with service-oriented values," a point also raised in Mathieu (2001) and Eggert et al. (2011). See Vargo and Lusch (2008) for a description of the "goods-dominant" and "service-dominant" logics in manufacturing firms.

${ }^{18}$ As a robustness check, we also estimate a fixed effects regression. The results, which are consistent with those obtained by the LDV model, are shown in appendix table 9.

${ }^{19}$ Our results are robust to the use of only one or two lags.
} 
may also decide to sell services with them. ${ }^{20}$ To identify a causal link between servitization and firm performance, we need a suitable instrumental variable, that is, a measure correlated with the decision to start selling services but uncorrelated with the dependent variable. This is not an easy task with the data at hand, as any information on the firm's balance sheet is very likely to be correlated with its performance. Hence, we propose an instrument based on the assumption that management practice spillovers exist across firms. We consider that firms observe and imitate their competitors and are more likely to start selling services if comparable firms in the neighborhood already do so. ${ }^{21}$ For each firm $i$ and year $t$ in our database, we compute the number of servitized firms in its industry and the decile of size (measured as the average number of workers over the period) weighted by the geographic distance to $i$. The distance between firms is the geodesic distance between the cities in which the two headquarters are located. ${ }^{22}$ For firms located in the same city, we use a measure of the internal distance of the city equal to $(2 / 3) \sqrt{A / \pi}$, where $A$ is the area of the city in $\mathrm{km}^{2}$ (Mayer and Zignago, 2011). Hence, our instrument varies by year, 2-digit industry, city, and firm size decile. ${ }^{23}$ We lag the instrument by two periods, as our endogenous variable is the decision to sell services at $t-1 .{ }^{24}$

A legitimate concern about the instrument is that it may be directly correlated with firm performance. Indeed, if selling services influences the competitiveness of firms, then changing the number of service suppliers in the neighborhood of a firm is very likely to alter the competition pressure it faces and thereby its performance. In this case, the exclusion restriction is not verified, and no inference can be drawn from the empirical results. Our empirical strategy addresses this issue in two ways. First, our instrument is lagged by two periods with respect to the dependent variable, Performance ${ }_{i, t}$. This should eliminate simultaneity bias that would lead to violation of the exclusion restriction. Second, our first- and second-stage regressions control for the past performance of firms (in $t-1$ and $t-2$ ). Any effect of our instrumental variable on past performance is therefore captured by these lags. It is quite unlikely that our instrumental variable influences the current performance of firms without influencing its performance in $t-1$ or $t-2$, a factor for which we explicitly control.

Finally, we need to define an appropriate control group given that our objective is to assess the impact of starting to sell services on firm performance. We compare the performance of firms that shift toward the provision of services to the performance of firms that do not (or have not yet started). In other words, we do not consider firms that sell services throughout the period. We also omit firms that stop selling services to avoid mixing

\footnotetext{
${ }^{20}$ Eggert et al. (2011) and Visnjic et al. (2014) show that servitization is more likely to generate better performance when it is coupled with product innovation.

${ }^{21} \mathrm{~A}$ vast empirical literature has shown that scanning the external environment to obtain information about competitors' practices is a determinant of management innovation at the firm level. See, for instance, Audretsch and Feldman (1996); McEvily and Zaheer (1999); Mol and Birkinshaw (2009) and Fu (2012).

${ }^{22}$ The French territory is divided into more than 36,500 cities with an average surface area of only 14.9 $\mathrm{km}^{2}$. This high level of administrative fragmentation makes our measure of distance between firms quite precise and offers substantial variation in the instrument across firms.

${ }^{23} \mathrm{We}$ also performed robustness analyses with an alternative instrument: the share of servitized firms in the same industry located in the same or surrounding départements (France is divided into 95 départements). The (unreported) results are very close to those reported in the paper.

${ }^{24}$ Our instrument is therefore lagged by only one period with respect to the endogenous variable. The first-stage regression also includes all other explanatory variables and year $\times$ industry fixed effects.
} 
the effects of shifting into services from those of shifting out of services. Given these restrictions and the large number of lags (\#Lags=3), the econometric identification relies on a sample of 6,392 individual firms and a total of 34,243 observations. Note that our results are robust to less restrictive alternative samples (see table 10 in the appendix).

In the following, the average treatment effect (ATE), $\alpha$ in equation (3), is estimated by full maximum likelihood with endogenous treatment, $\mathbb{1}\left(\operatorname{ser} v_{i, t-1}\right)$. The first-stage equation is a probit regression, which predicts the probability of treatment (i.e., the probability that a firm starts selling services). In all specifications, the instrument provides a good fit in the first stage. The instrument has a significantly positive impact on the probability of producing services and passes the usual validity tests.

\subsection{Baseline econometric results}

\subsubsection{Profitability}

We begin our presentation of the econometric results by examining the impact of servitization on the profitability of firms in detail.

The benchmark results are displayed in table 2 . The coefficient on $\mathbb{1}\left(\operatorname{ser} v_{i, t-1}\right)$ is the ATE of starting to sell services in the previous year. Columns (1) and (4) show simple OLS estimates of the relationship between the lagged servitization dummy and the profit rate, excluding and including control for lagged employment, respectively. These specifications, which do not take into account omitted variable or reverse causality issues, yield simple premia of servitization that are comparable to those shown in figure $7 .{ }^{25}$ The estimates confirm the existence of a significant premium. The profitability of firms that start selling services is 4.2 percentage points higher than that of pure manufacturers ( 4.4 when controlling for lagged employment). In the sample used for the regressions, the average profit rate is $45.7 \%$, which implies a premium on the profit rate between $9.2 \%$ and $9.6 \%$, depending on whether we control for the number of employees. In columns (2) and (5), we control for the lagged values of the profit rate in order to account for selection effects. Unsurprisingly, the ATE decreases, confirming that most of the premium comes from self-selection. The impact of servitization remains positive but is much smaller. Starting to sell services is associated with an increase in the profit rate of between 0.4 and 0.47 percentage points.

In columns (3) and (6), we properly control for endogeneity by instrumenting the decision to start selling services. The ATE is between 1.7 and 2.4 percentage points, which corresponds to a causal increase in the profit rate between 3.7 and $5.3 \%$. The fact that the instrumental variable estimation provides a larger ATE reveals a negative endogeneity bias, which suggests that the shift toward the provision of services is driven by a quite strong defensive motive. It seems that, everything else equal, firms that start selling services anticipate a relative decline in their profitability.

Tables 9 and 10 in the appendix present a series of robustness checks. In table 9, we use alternative estimators and sets of controls. In line (1), we control for potential

\footnotetext{
${ }^{25}$ The results shown in figure 7 are slightly different because they are based on sample of observations that is not restricted by the use of lagged variable or a precise control group.
} 
determinants of profitability: the lagged firm market share (the firm's sales of goods divided by the total sales of goods in the same industry) and the interaction between this market share and the lagged industry-level Herfindahl index, which captures the level competition in the industry. ${ }^{26}$ The ATE is 2.46 , which is not statistically different from the benchmark regression (2.427, in column (6) of table 2). In lines (2)-(4), we report the ATE obtained using a fixed effect estimator instead of an LDV model. In line (2), we control only for the lagged employment level and do not instrument the treatment variable. Line (3) shows the ATE using an instrumental variable, and line (4) further controls for the firm's market share and its interaction with the Herfindahl index. The ATEs are always positive and significant, which confirms that starting to sell services boosts firm profitability. Again, we observe that the instrumental variable estimates are substantially greater than the OLS estimates. Note also that the fixed effects estimates are systematically larger than those of the LDV models. With fixed effects, the ATE is approximately 4.6 (cf. lines (3) and (4) of table 9) compared to 2.4 with the LDV model (cf. column (6) of table 2). This is consistent with the bracketing properties of these two estimators, as described by Angrist and Pischke (2008). If the correct model is an LDV model, then fixed effects will result in the overestimation of a positive treatment effect. However, if the most important omitted variables are time invariant, the correct model is a fixed effects model, and the LDV estimator will result in an underestimation of the treatment effect. While we argue that the correct specification in our case is the LDV model, it is useful to think of our estimates as lower bounds of the true causal effect.

In table 10 , we test the robustness of our benchmark results to an alternative sample of firms. In our benchmark regression (table 2), we exclude firms that always sold services or that stopped selling services over the study period. We focused on the subsample of firms that either never sold services and that started to sell services. In line (1) of table 10, we exclude all firm that produced services during the year $\mathrm{t}-2$. In other words, we use a sharper definition of the treatment. We exclude from the sample all treated firms once they have been treated (i.e., once they have started to produce services), and we estimate the impact of shifting toward services in the year after the shift but not in the following years. In line (2), we add to our benchmark sample firms that stop the production of services, and in line (3), we replicate our benchmark regression using the sample of firms that are always observed in our database (i.e., we exclude firms that appeared or disappeared between 1997 and 2007). We confirm that servitization has a positive influence on firm profitability. The point estimates obtained from these alternative samples are slightly larger than that reported in table 2. This further confirms that our preferred result is a conservative estimate of the impact of servitization on firm profitability.

\subsubsection{Employment, turnover and production of goods}

We now turn to the inspection of the impact of servitization on alternative indicators of firm performance. We re-estimate equation (3) using level of employment, turnover and production of goods as alternative dependent variables. The baseline results are shown in table 3. As a robustness check, we report the fixed effects estimates in table 11 . The results confirm the positive impact of servitization. Once again, the fixed effects estimates

\footnotetext{
${ }^{26}$ We do not include the Herfindahl index on its own because it is fully captured by the industry $\times$ year fixed effect.
} 
Table 2 - Impact of Servitization on Firm Profitability - Benchmark Results

\begin{tabular}{lcccccc}
\hline \hline Dep. var.: Profit & $(1)$ & $(2)$ & $(3)$ & $(4)$ & $(5)$ & $(6)$ \\
Estimator: & OLS & LDV & LDV-IV & OLS & LDV & LDV-IV \\
\hline $\mathbb{1}\left(\right.$ serv $\left._{i, t-1}\right)$ & $4.179^{a}$ & $0.468^{a}$ & $1.669^{a}$ & $4.418^{a}$ & $0.399^{a}$ & $2.427^{a}$ \\
& $(0.284)$ & $(0.109)$ & $(0.322)$ & $(0.374)$ & $(0.112)$ & $(0.578)$ \\
Profit $_{i, t-1}$ & & $0.601^{a}$ & $0.599^{a}$ & & $0.601^{a}$ & $0.597^{a}$ \\
& & $(0.011)$ & $(0.011)$ & & $(0.011)$ & $(0.010)$ \\
Profit $_{i, t-2}$ & & $0.183^{a}$ & $0.182^{a}$ & & $0.183^{a}$ & $0.181^{a}$ \\
& & $(0.010)$ & $(0.010)$ & & $(0.010)$ & $(0.010)$ \\
Profit $_{i, t-3}$ & & $0.127^{a}$ & $0.126^{a}$ & & $0.127^{a}$ & $0.125^{a}$ \\
& & $(0.008)$ & $(0.008)$ & & $(0.008)$ & $(0.008)$ \\
Ln Employment $_{i, t-1}$ & & & & $-0.296^{c}$ & $0.084^{b}$ & -0.122 \\
& & & & $(0.151)$ & $(0.042)$ & $(0.078)$ \\
\hline \# Obs. & 34,243 & 34,243 & 34,243 & 34,243 & 34,243 & 34,243 \\
R $^{2}$ & 0.014 & 0.740 & & 0.014 & 0.740 & \\
$\rho$ & & & -0.0951 & & & -0.156 \\
Wald test (p-value) & & & $(0.000)$ & & & $(0.000)$ \\
\hline
\end{tabular}

Notes: All regression include industry $\times$ year fixed effects. Robust standard errors in parentheses are clustered by industry $\times$ year. Significance levels: $c: p<0.1,{ }^{b}: p<0.05,{ }^{a}: p<0.01$. Coefficients on $\mathbb{1}\left(\operatorname{serv}_{i, t-1}\right)$ are the average treatment effects (ATEs). Columns (3) and (6) report full maximum likelihood estimations, where the treatment variable, $\mathbb{1}\left(\operatorname{serv}_{i, t-1}\right)$, is instrumented by the (2-year lagged) distance-weighted sum of servitized firms in the corresponding industry and size decile. The Wald test $(\rho=0)$ is below $10 \%$, indicating that we can reject the null hypothesis of no correlation between the treatment and the outcome errors.

are a bit larger than those of the LDV (except for employment), which implies that the ATE shown in table 3 is a conservative lower bound of the true causal effect. ${ }^{27}$

As for profitability, we find a significant, positive causal impact of servitization on firm outcomes. Because each dependent variable is in logarithmic form, the magnitude of the estimated impact of starting the production of services is given by the exponent of the ATE. On average and relative to pure manufacturers, firms that start producing services increase their level of employment by approximately $30 \%(\exp (0.263) \cong 1.30)$, turnover by $3.7 \%$, and sales of goods by $3.6 \%$. The magnitude of these causal effects might seem very large, especially the impact on the number of employees. However, one has to keep in mind that most firms in our sample are small businesses. The marginal effects estimated here apply to relatively small values. For instance, the median firm in our sample has no more than 9 employees. A 30\% increase in the number of employees represents two additional jobs for the median firm.

\subsection{Extensions}

All econometric results shown above point in the same direction. They confirm that servitization has a positive causal impact on the performance of manufacturing firms. These

\footnotetext{
${ }^{27}$ For the sake of conciseness, we do not report all robustness analyses. We have also checked the robustness of these results to alternative models, samples of firms and control groups. All unreported estimates corroborate those shown in table 3. They are available from the authors upon request.
} 
Table 3 - Impact of Servitization on Firm Employment, Turnover, and Production of Goods - Lagged Dependent Variable Model

\begin{tabular}{llcccc}
\hline \hline & Dep. variable & ATE & std. err. & \# Obs. & $\rho$ (p-value) \\
\hline (1) & Employment & $0.263^{a}$ & $(0.019)$ & 34,243 & $-0.593(0.000)$ \\
$(2)$ & Turnover & $0.036^{a}$ & $(0.009)$ & 34,243 & $-0.069(0.001)$ \\
$(3)$ & Prod. goods & $0.035^{a}$ & $(0.008)$ & 34,243 & $-0.072(0.000)$ \\
\hline \hline
\end{tabular}

Notes: Lagged dependent variable models with 3 lags, controlling for industry $\times$ year fixed effects in all regressions and for lagged employment in (2) and (3). The treatment variable, $\mathbb{1}\left(\operatorname{ser} v_{i, t-1}\right)$, is instrumented by the (2-year lagged) distance-weighted sum of servitized producers in the corresponding industry and size decile. Estimators: two-step (line 1) and full maximum likelihood (lines 2 and 3 ). The (std. err.) column reports robust standard errors clustered by industry $\times$ year. Significance levels: ${ }^{c}: \mathrm{p}<0.1,{ }^{b}: \mathrm{p}<0.05,{ }^{a}: \mathrm{p}<0.01$.

econometric results contrast with the many case studies that highlight the difficulties companies experience with reaping the benefits of a servitization strategy (Gebauer et al., 2005; Martinez et al., 2010) However, our estimates are only average effects, which may hide heterogeneity by industry or firm type. In this section, we evaluate the consequence of starting to sell services on the long-run performance of various sub-samples of firms. These more detailed results indicate that the impact of servitization on firm performance is much less systematic than suggested by our benchmark regressions.

\subsubsection{Long-run effects}

As emphasized in the literature, selling services is associated with long-term investments with consumers, and the benefits of servitization may take time to materialize. Our baseline specification has considered firm performance in the year following a move toward services. Thus, our results may miss some of the long-run effects of servitization. In the following table, we present results for how firm performance is affected at $t+1, t+2$ and $t+3$ by the move toward services. ${ }^{28}$

The results indicate that the consequence of servitization on firm profitability are spread over time. Our benchmark results indicate that in the year after a shift toward services, servitized firms increase their profit rate by 2.42 percentage points compared to pure manufacturers (see table 2). Table 4 shows that this gap grows steadily for at least three years, reaching 4.3 percentage points by year $t+3$. The impact on employment is also persistent, but the dynamics are clearly different, as the effect decreases slowly over time. Four years after the switch, we still observe a significant causal impact of servitization on the number of employees $(\exp (0.138)-1 \cong 14.8 \%)$, but this effect is half the size of that observed the year following the switch $(\exp (0.263)-1 \cong 30.1 \%)$. The impacts on turnover and production of goods also fade over time but at faster rates. Four years after the shift toward services, the causal effect of servitization on production is very small and barely significant, and the impact on the production of goods is no longer visible. All together, these results suggest that the supply of services does not really support the production of goods over the long run. Servitization seems to be mainly a strategy that leads firms to focus on their most profitable activities and/or to differentiate their

\footnotetext{
${ }^{28}$ Because of data limitations, we cannot estimate the impact of servitization over a longer period.
} 
products further in order to charge higher margins.

Table 4 - Impact of Servitization on Firm Performance - Long-run Effects

\begin{tabular}{cccccc}
\hline \hline & ATE & std. err. & \# Obs. & $\rho(\mathrm{p}$-value $)$ & Dependent variable \\
\hline$(1)$ & $2.6246^{a}$ & $(0.962)$ & 27,851 & $-0.183(0.015)$ & Profit $_{i, t+1}$ \\
$(2)$ & $3.204^{a}$ & $(1.239)$ & 22,360 & $-0.232(0.015)$ & Profit $_{i, t+2}$ \\
$(3)$ & $4.306^{a}$ & $(1.004)$ & 17,486 & $-0.314(0.000)$ & Profit $_{i, t+3}$ \\
\hline$(4)$ & $0.194^{a}$ & $(0.020)$ & 27,851 & $-0.458(0.000)$ & $\ln (\text { Emp. })_{i, t+1}$ \\
$(5)$ & $0.161^{a}$ & $(0.022)$ & 22,360 & $-0.400(0.000)$ & $\ln (\text { Emp. })_{i, t+2}$ \\
$(6)$ & $0.138^{a}$ & $(0.024)$ & 17,486 & $-0.351(0.000)$ & $\ln (\text { Emp. })_{i, t+3}$ \\
\hline$(7)$ & $0.027^{a}$ & $(0.010)$ & 27,851 & $-0.056(0.013)$ & $\ln (\text { Turnover })_{i, t+1}$ \\
$(8)$ & 0.013 & $(0.015)$ & 22,360 & $-0.027(0.466)$ & $\ln (\text { Turnover })_{i, t+2}$ \\
$(9)$ & $0.016^{c}$ & $(0.009)$ & 17,486 & $-0.037(0.054)$ & $\ln (\text { Turnover })_{i, t+3}$ \\
\hline$(10)$ & $0.023^{b}$ & $(0.010)$ & 27,851 & $-0.043(0.052)$ & $\ln (\text { Prod.goods })_{i, t+1}$ \\
$(11)$ & -0.002 & $(0.040)$ & 22,360 & $0.013(0.895)$ & $\ln \left(\right.$ Prod.goods $_{i, t+2}$ \\
$(12)$ & 0.013 & $(0.009)$ & 17,486 & $-0.025(0.223)$ & $\ln \left(\right.$ Prod.goods $_{i, t+3}$ \\
\hline \hline
\end{tabular}

Notes: Lagged dependent variable models with 3 lags, controlling for lagged employment (except for lines 4-6) and industry $\times$ year fixed effects. The treatment variable, $\mathbb{1}\left(\operatorname{serv} v_{i, t-1}\right)$, is instrumented by the (2-year lagged) distance-weighted sum of servitized producers in the corresponding industry and size decile. Estimators: full maximum likelihood (lines 1-3 and 7-12) and two-step (lines 4-6). Column (std. err.) reports robust standard errors clustered by industry $\times$ year. Column $(\rho)$ reports the value of $\rho$ and the corresponding p-value of the Wald test of the exogeneity of the instrumented variables. Significance levels: ${ }^{c}: p<0.1, b: p<0.05$, a: $p<0.01$.

\subsubsection{Results by firm size}

In table 5, we examine whether the impact of servitization differs by firm size. We report the ATE estimated from samples of micro, small, and medium and large firms, as defined by the European Commission. ${ }^{29}$

For each of the four performance measures, we observe quite strong effects for micro and small businesses. For micro firms, starting to produce services is associated with an increase in the profit rate of 2.8 percentage points (which corresponds to an average increase of approximately $6 \%$ given the average level of the profit rate for this group of firms). Starting to sell services also increases employment, turnover and production for these firms. The impact on employment is particularly large $(25 \%)$ but represents a limited number of new jobs given the small size of these firms. In our sample, the median micro firm employs only 5 workers, ${ }^{30}$ so the estimated impact of servitization corresponds to an increase of 1.25 workers in this category. For small firms, the impact on profitability if larger. The ATE is more than 3.1 percentage points, which corresponds to an average increase in the profit rate of $7.2 \%$. Employment grows by more than $38 \%$, which represents slightly less than 7 new jobs in the median small firm. ${ }^{31}$

\footnotetext{
${ }^{29}$ Firms are classified according to their average number of employees over the observation period. Micro firms have no more than 10 employees. Small firms have between 11 and 50 employees, and medium and large firms have more than 50 employees.

${ }^{30}$ The average number of workers in this class of firm is very close to the median: 5.48 .

${ }^{31}$ The median number of workers in this category 18.
} 
In contrast, we do not observe a significant impact of servitization on the performance of medium and large firms (i.e., firms with more than 50 employees). This non-significance may be due to the relatively small number of firms in this category (especially of switching firms), which reduces the precision of the estimates. This pattern may also indicate that firms that have managed to grow without feeling the need to produce services perform particularly well in the production of goods.

Table 5 - Impact of Servitization on Firm Profitability, Employment, Turnover, and Production of Goods - By Firm Size

\begin{tabular}{lllllcl}
\hline \hline & Dep. variable & ATE & std. err. & $\#$ Obs. & $\rho$ (p-value) & $\begin{array}{c}\text { Firm type } \\
\text { (\# employees) }\end{array}$ \\
\hline$(1)$ & Profitability & $2.786^{a}$ & $(0.590)$ & 18,643 & $-0.161(0.000)$ & micro $(1-10)$ \\
$(2)$ & Profitability & $3.127^{c}$ & $(1.274)$ & 12,519 & $-0.222(0.043)$ & small $(11-50)$ \\
$(3)$ & Profitability & 2.300 & $(1.632)$ & 3,081 & $-0.196(0.177)$ & large $(>50)$ \\
\hline$(4)$ & Employment & $0.226^{a}$ & $(0.158)$ & 18,643 & $-0.449(0.000)$ & micro $(1-10)$ \\
$(5)$ & Employment & $0.327^{a}$ & $(0.030)$ & 12,519 & $-0.823(0.000)$ & small $(11-50)$ \\
$(6)$ & Employment & -0.038 & $(0.082)$ & 3,081 & $-0.199(0.000)$ & large $(>50)$ \\
\hline$(7)$ & Turnover & $0.030^{a}$ & $(0.011)$ & 18,643 & $-0.068(0.000)$ & micro $(1-10$ \\
$(8)$ & Turnover & $0.086^{a}$ & $(0.021)$ & 12,519 & $-0.185(0.002)$ & small $(11-50)$ \\
$(9)$ & Turnover & 0.022 & $(0.126)$ & 3,081 & $-0.082(0.819)$ & large $(>50)$ \\
\hline$(10)$ & Prod. goods & $0.023^{b}$ & $(0.011)$ & 18,643 & $-0.063(0.000)$ & micro $(1-10$ \\
$(11)$ & Prod. goods & $0.083^{a}$ & $(0.017)$ & 12,519 & $-0.180(0.000)$ & small $(11-50)$ \\
$(12)$ & Prod. goods & 0.168 & $(0.123)$ & 3,081 & $-0.467(0.185)$ & large $(>50)$ \\
\hline \hline
\end{tabular}

Notes: Lagged dependent variable models with 3 lags, controlling for lagged employment and industry $\times$ year fixed effects. The treatment variable is instrumented by the (2-year lagged) distanceweighted sum of servitized producers in the corresponding industry and size decile. Estimators: Full maximum likelihood (lines 1-3 and 7-12) and two-step (lines 4-6). Column (2) reports robust standard errors clustered by industry-year. Column (4) reports the value of $\rho$ and the corresponding $P$-value of the Wald test of the exogeneity of the instrumented variables. Significance levels: $c$ : $\mathrm{p}<0.1,{ }^{b}: \mathrm{p}<0.05,{ }^{a}: \mathrm{p}<0.01$.

\subsubsection{Results by industry}

Moving toward supplying services to consumers is very likely to depend on the characteristics of the product being sold or on the type of competition prevailing within an industry. Using the same dataset, in Crozet and Milet (2014), we show that servitization is more widespread in industries that produce heterogeneous goods. ${ }^{32}$ Fang et al. (2008) provide evidence that adding a service to the core product of the firm leads to higher market value, especially in industries with overall low growth and high volatility of sales. In a widely cited article, Teece (1986) argued that services "do not loom large" in the early stages of an industry. This influenced the vision that services are beneficial when firms

\footnotetext{
${ }^{32}$ We use data on the firm-level exports of goods from French customs data and use Rauch (1999)'s classification to distinguish between differentiated and homogenous goods. We find a positive log-linear relationship between the average share of services of the industry's output and the share of differentiated products in this industry. This argument is in line with Anderson et al. (1997), who argue that firm performance depends on the degree of heterogeneity of their product. In their paper, they link measures of productivity to customer satisfaction (which takes into account the standardization versus the customization quality of the product).
} 
enjoy a well-established base of customers and as differentiation of the product becomes increasingly difficult. This view has been recently challenged by authors, such as Suarez et al. (2013) and Cusumano et al. (2015), who note that services can be offered before, during, or after the purchase of the good. ${ }^{33}$ To show how the impact of servitization differs by sector, we have assigned each firm in our database to a broadly defined sector and estimated equation (3) for each group separately. ${ }^{34}$ The results are reported in table 6 . Table 12 in the appendix shows the comparable results obtained for the sample of micro and small businesses.

Again, this table conveys a more complex message about the consequence of servitization. At first sight, this table confirms the positive impact of servitization on firm performance, as a very large majority of the estimates are significantly positive (of the 28 estimates reported in this table, 16 are significantly positive, 8 are non-significant, and only 4 are negative). However, the results differ substantially across sectors and reveal both the complexity and the diversity of the servitization strategies discussed in the literature. We can identify three patterns:

1. Servitization has a positive impact on all four indicators of performance. This is the case for agri-food (1) and other manufacturing not elsewhere classified (7). For these two industries (particularly the latter group), the estimated impact is quite large but close to that of the pooled results.

2. Servitization increases the sales of goods (and more generally firm size) but not the profit rate. This is clearly the case for mineral and metal products (4) as well as for textile (2) (wherein turnover and sales of goods, but not employment, are positively affected). Here, sales of services are positively correlated with sales of goods. However, the service offering is not a strategy that increases profitability, either because producing complementary services is not enough to provide a significant competitive advantage or because the cost of organizing services activities outweighs (at least over the short-run) the competitive gains.

3. Servitization increases profitability, but a substitution effect between services and goods prevails. This is the case for wood products, paper and printing (3) and chemicals and plastics (4). ${ }^{35}$ The substitution effect observed suggests that the decision to supply services is a part of a broader strategy in which the firms focus on their most profitable activities or markets. ${ }^{36}$

\footnotetext{
${ }^{33} \mathrm{~A}$ very often-cited example is IBM, which introduced the first computers for businesses in the 1950s. These products were expensive and unknown to consumers. IBM engaged in leasing contracts, which were combined with maintenance, and pay-for-usage contracts. Services preceded and substituted for the sale of these products.

${ }^{34}$ All regressions control for 2-digit industry fixed effects.

${ }^{35}$ For the latter sector, the results are less clear than suggested by table 6 . The negative impact on turnover and sales of goods shown in table 6 is entirely driven by the largest firms. Table 12 shows that for micro and small firms in this sector, servitization increases production.

${ }^{36}$ Note that we find no significant impact in sector 6 (machinery, electrical, optical and transport equipment), except a small and very imprecisely estimated coefficient for the number of employees. This perhaps surprising result is mostly due to the behavior of the largest firms. When we consider only micro and small firms, we obtain a positive and significant impact of servitization on profitability and employment (see table 12).
} 
Table 6 - Impact of Servitization - By Sector

\begin{tabular}{|c|c|c|c|c|}
\hline & ATE & std. err. & \# Obs. & $\rho$ (p-value) \\
\hline \multicolumn{5}{|c|}{ 1- Food, Beverage, Tobacco } \\
\hline Profitability & $5.070^{a}$ & $(0.511)$ & 10479 & $-0.390(0.000)$ \\
\hline Ln Employment & $0.178^{a}$ & $(0.034)$ & 10479 & $-0.376(0.000)$ \\
\hline Ln Turnover & $0.026^{b}$ & $(0.0$ & 10479 & $0.214(0.095)$ \\
\hline Ln Prod. goods & $0.024^{c}$ & & 10479 & -0.066 \\
\hline \multicolumn{5}{|c|}{ 2- Textile, Leather } \\
\hline Profitability & -1.268 & $(2.339)$ & 1258 & $0.065(0.629)$ \\
\hline Ln Employment & 0.070 & & 1258 & $5(0.662)$ \\
\hline Ln Turnover & $0.225^{b}$ & & 1258 & $0.357(0.003)$ \\
\hline Ln Prod. goods & $0.214^{a}$ & $(0.1$ & 1258 & $0.006)$ \\
\hline \multicolumn{5}{|c|}{ 3- Wood, Paper, Printing } \\
\hline Profitability & $6.632^{a}$ & $(2.040)$ & 4776 & $-0.453(0.05)$ \\
\hline Ln Em & -0.080 & & 4776 & $5(0.365)$ \\
\hline Ln Tur & $-0.353^{a}$ & & 4776 & $45(0.000)$ \\
\hline Ln Prod. goods & $-0.357^{a}$ & & 4776 & $.000)$ \\
\hline \multicolumn{5}{|c|}{ 4- Chemicals, Plastics } \\
\hline Profitability & $9.690^{a}$ & & 1527 & -0.630 \\
\hline yyment & -0.185 & & 1527 & $84(0.381)$ \\
\hline Ln Tur & $-0.237^{b}$ & & 1527 & $54(0.025)$ \\
\hline Ln Prod. goods & $-0.248^{b}$ & & 1527 & 0.566 \\
\hline \multicolumn{5}{|c|}{ 5- Mineral, Metal Products } \\
\hline Profitability & 2.860 & & 9941 & 443) \\
\hline yment & $0.096^{c}$ & & 1 & $.099)$ \\
\hline Ln Tur & $0.044^{b}$ & & 9941 & $0.106)$ \\
\hline Ln Prod. goods & $0.023^{b}$ & $(0.0$ & 9941 & $.622)$ \\
\hline \multicolumn{5}{|c|}{ 6- Machinery, Electrical Equip. } \\
\hline Profitability & 1.220 & $(0.917)$ & 4309 & $0.634)$ \\
\hline loyment & $0.190^{c}$ & & 4309 & $0.096)$ \\
\hline Ln Turnover & 0.021 & & 4309 & $-0.035(0.163)$ \\
\hline Ln Prod. goods & 0.021 & & 4309 & $44(0.023)$ \\
\hline \multicolumn{5}{|c|}{ 7- Manufacturing, n.e.c. } \\
\hline Profitability & & & 1953 & $9.085(0.000)$ \\
\hline Ln Employment & $0.387^{b}$ & $(0.179)$ & 1953 & $-0.749(0.050)$ \\
\hline Ln Turnover & $0.102^{a}$ & & & $-0.191(0.134)$ \\
\hline Ln Prod. goods & $0.093^{a}$ & $(0.057)$ & 1953 & $-0.178(0.133)$ \\
\hline
\end{tabular}

Notes: Lagged dependent variable model with 3 lags, controlling for lagged employment and industry $\times$ year fixed effects. All lines report estimates by full maximum likelihood (except for employment: two steps), where the treatment variable, $\mathbb{1}\left(\operatorname{serv}_{i, t-1}\right)$, is instrumented by the (2-year lagged) distance-weighted sum of servitized producers in the corresponding industry and size decile. Column (std. err.) reports robust standard errors clustered by industry $\times$ year. Significance levels: ${ }^{c}: \mathrm{p}<0.1,{ }^{b}: \mathrm{p}<0.05,{ }^{a}: \mathrm{p}<0.01$. 


\section{Conclusion}

Servitization is growing everywhere, yet empirical evidence of its impact on firm performance remains scarce (Baines and Lightfoot, 2013). We contribute to filling this gap by documenting the extent and evolution of servitization in the French manufacturing sector between 1997 and 2007 using a large dataset of more than 50,000 servitized and non-servitized firms. We first documented that the vast majority of French manufacturing firms report positive sales of services. While the share of servitized firms remained quite stable over the 1997-2007 period, we find that the share of services of total production sales increased in all industries and, on average, in each firm. We showed that servitized firms are more profitable, employ more workers, and have higher total sales than nonservitized firms. These premia depend greatly on whether firms sell services, but they do not vary with the share of services in production sales. Building on this result, we adopted a micro-econometric approach to assess the causal impact of engaging in the production of services on firm performance. We find that, compared to firms that produce goods only, firms that start selling services increase their profitability by $3.7 \%$ to $5.3 \%$, increase their number of employees by $30 \%$, and boost their sales of goods by $3.6 \%$. From an academic perspective, several interesting questions that are beyond the scope of this paper are raised. Firms that complement their products with services have shifted toward a new business model. Their activities have become a mix of goods and services and no longer produce only tangible products. This raises the question of the relevance of unique industry classifications based on the main activity of a firm. How should firms that produce as many goods as services be classified? On a more theoretical note, this paper raises the question of how to define the production functions of such firms. It also calls into question the definition and proper calculation of the total factor productivity of these firms.

\section{References}

Acemoglu, D. and Guerrieri, V. (2008). Capital Deepening and Nonbalanced Economic Growth. Journal of Political Economy, 116(3):467-498.

Anderson, E. W., Fornell, C., and Rust, R. T. (1997). Customer Satisfaction, Productivity, and Profitability: Differences Between Goods and Services. Marketing Science, 16(2):129-145.

Angrist, J. and Pischke, J.-S. (2008). Mostly Harmless Econometrics: An Empiricist's Companion. Princeton University Press.

Audretsch, D. B. and Feldman, M. P. (1996). R\&D Spillovers and the Geography of Innovation and Production. American Economic Review, 86(3):630-40.

Baines, T. and Lightfoot, H. (2013). Made to Serve: How Manufacturers Can Compete Through Servitization and Product Service Systems. Wiley.

Baines, T., Lightfoot, H., Benedettini, O., and Kay, J. (2009). The Servitization of Manufacturing: A review of literature and reflection on future challenges. Journal of Manufacturing Technology Management, 20(5):547-567.

Baumol, W. J. (1967). Macroeconomics of Unbalanced Growth: The Anatomy of Urban Crisis. American Economic Review, 57(3):415-426. 
Benedettini, O., Clegg, B., Kafouros, M., and Neely, A. (2010). The Ten Myths of Manufacturing. What Does the Future Hold for UK Manufacturing? Report prepared for the engineering and physical science research council.

Benedettini, O., Swink, M., and Neely, A. (2013). Firm's Characteristics and Servitization Performance: A Bankruptcy Perspective. University of cambridge, cambridge service alliance working paper.

Bernard, A. B. and Fort, T. C. (2013). Factoryless Goods Producers in the U.S. NBER Working Papers 19396.

Bowen, D. E., Siehl, C., and Schneider, B. (1989). A Framework for Analyzing Customer Service Orientations in Manufacturing. The Academy of Management Review, 14(1):pp. 75-95.

Breinlich, H., Soderbery, A., and Wright, G. C. (2014). From Selling Goods to Selling Services: Firm Responses to Trade Liberalization. C.E.P.R. Discussion Papers 10116.

Crozet, M. and Milet, E. (2014). The Servitization of French Manufacturing Firms. CEPII Working Paper 2014-10.

Cusumano, M. A., Kahl, S. J., and Suarez, F. F. (2015). Services, Industry Evolution, and the Competitive Strategies of Product Firms. Strategic Management Journal, 36(4):559-575.

Eggert, A., Hogreve, J., Ulaga, W., and Muenkhoff, E. (2011). Industrial Services, Product Innovations, and Firm Profitability: A Multiple-group Latent Growth Curve Analysis. Industrial Marketing Management, 40(5):661 - 670.

European Commission, T. (2014). For a European Industrial Renaissance, Communication from the Commission to the European Parliament, The Council, The European Economic and Social Committee and the Committee of the Regions.

Fang, E., Palmatier, W. R., and Steenkamp, J.-B. E. (2008). Effect of Service Transition Strategy on Firm Value. Journal of Marketing, 72(5):1-14.

Fu, X. (2012). Foreign Direct Investment and Managerial Knowledge Spillovers through the Diffusion of Management Practices. Journal of Management Studies, 49(5):970999.

Fuchs, V. R. (1968). The Service Economy. Number 87. NBER.

Gebauer, H. and Fleisch, E. (2007). An Investigation of the Relationship Between Behavioral Processes, Motivation, Investments in the Service Business and Service Revenue. Industrial Marketing Management, 36(3):337 - 348.

Gebauer, H., Fleisch, E., and Friedli, T. (2005). Overcoming the Service Paradox in Manufacturing Companies. European Management Journal, 23(1):14-26.

Lodefalk, M. (2013). Servicification of Manufacturing - Evidence from Sweden. International Journal of Economics and Business Research, 6(1):87-113.

Martinez, V., Bastl, M., Kingston, J., and Evans, S. (2010). Challenges in Transforming Manufacturing Organisations into Product-service Providers. Journal of Manufacturing Technology Management, 21(4):449-469.

Mathieu, V. (2001). Service strategies within the manufacturing sector: benefits, costs and partnership. International Journal of Service Industry Management, 12(5):451-475.

Mayer, T. and Zignago, S. (2011). Notes on CEPII's Distances Measures: The GeoDist 
Database. CEPII Working Papers 2011-25.

McEvily, B. and Zaheer, A. (1999). Bridging Ties: A Source of Firm Heterogeneity in Competitive Capabilities. Strategic Management Journal, 20(12):1133-1156.

Mol, M. J. and Birkinshaw, J. (2009). The Sources of Management Innovation: When Firms Introduce New Management Practices. Journal of Business Research, 62(12):1269-1280.

Neely, A. (2008). Exploring the Financial Consequences of the Servitization of Manufacturing. Operations Management Research, 1(2):103-118.

Neely, A., Benedittini, O., and Visnjic, I. (2011). The Servitization of Manufacturing: Further Evidence. Euoma conference, cambridge.

Ngai, L. R. and Pissarides, C. A. (2007). Structural Change in a Multisector Model of Growth. American Economic Review, 97(1):429-443.

Oliva, R. and Kallenberg, R. (2003). Managing the Transition from Products to Services. International Journal of Service Industry Management, 14(2):160-172.

Pilat, D., Cimper, A., Olsen, K., and Webb, C. (2006). The Changing Nature of Manufacturing in OECD Economies. STI Working Paper 9.

Rauch, J. E. (1999). Networks Versus Markets in International Trade. Journal of International Economics, 48(1):7-35.

Reinartz, W. and Ulaga, W. (2008). How to Sell Services More Profitably. Harvard Business Review, 86(5):90-98.

Stigler (1956). Trends in Employment in the Service Industries. National Bureau of Economic Research, General Series n.59.

Suarez, F. F., Cusumano, M. A., and Kahl, S. J. (2013). Services and the Business Models of Product Firms: An Empirical Analysis of the Software Industry. Management Science, 59(2):420-435.

Teece, D. J. (1986). Profiting from Technological Innovation: Implications for Integration, Collaboration, Licensing and Public Policy. Research Policy, 15(6):285-305.

Vandermerwe, S. and Rada, J. (1988). Servitization of Business: Adding Value by Adding Services. European Management Journal, 6(4):314-324.

Vargo, S. L. and Lusch, R. F. (2008). From Goods to Service(s): Divergences and Convergences of Logics. Industrial Marketing Management, 37(3):254 - 259.

Visnjic, I., Wiengarten, F., and Neely, A. (2014). Only the Brave: Product Innovation, Service Business Model Innovation, and Their Impact on Performance. Journal of Product Innovation Management, page DOI: 10.1111/jpim.12254.

Wilkins, A. S. (2015). To Lag or Not to Lag? Re-evaluating the Use of Lagged Dependent Variables in Regression Analysis. mimeo.

Wise, R. and Baumgartner, P. (1999). Go Downstream in Manufacturing. Harvard Business Review, 135. 


\section{Appendix}

\subsection{Summary statistics - complete sample}

Table 7 - Summary Statistics - Sample including Firms with a Share of Services of Total Sales above $50 \%$

\begin{tabular}{|c|c|c|c|c|c|c|c|}
\hline & \multicolumn{3}{|c|}{ All firms } & \multicolumn{3}{|c|}{ Servitized firms } \\
\hline & & 1997 & 2007 & $\Delta 97-07$ & 1997 & 2007 & $\Delta 97-07$ \\
\hline \multirow[t]{2}{*}{ (1) } & \# Firms & 31,603 & 28,258 & -1.11 & 23,345 & 21,007 & -1.02 \\
\hline & Share $(\%)$ & & & & 73.9 & 74.6 & \\
\hline \multirow[t]{4}{*}{ (2) } & Employment & & & & & & \\
\hline & Total (thousand) & 1,905 & 1,618 & -1.62 & 1,677 & 1,473 & -1.29 \\
\hline & Share $(\%)$ & & & & 88.0 & 91.0 & \\
\hline & Average & 60.27 & 57.27 & -0.51 & 71.8 & 69.7 & -0.28 \\
\hline \multirow[t]{4}{*}{ (3) } & Turnover & & & & & & \\
\hline & Total $(€$, million $)$ & 333.1 & 415.8 & +2.24 & 298.8 & 387.6 & +2.64 \\
\hline & Share $(\%)$ & & & & 89.7 & 93.2 & \\
\hline & Average ( $€$, thousand) & 10.5 & 14.7 & +3.39 & 12.8 & 18.4 & +3.69 \\
\hline \multirow[t]{4}{*}{ (4) } & Production of goods & & & & & & \\
\hline & Total (€, million) & 281.0 & 334.6 & +1.76 & 247.6 & 307.0 & +2.17 \\
\hline & Share $(\%)$ & & & & 88.1 & 91.7 & \\
\hline & Average ( $€$, thousand) & 8.9 & 11.8 & +2.91 & 10.6 & 14.6 & +3.22 \\
\hline \multirow[t]{2}{*}{ (5) } & Profitability & & & & & & \\
\hline & Average (\%) & 47.0 & 48.7 & +0.35 & 47.7 & 49.8 & +0.43 \\
\hline \multirow[t]{4}{*}{ (6) } & Service intensity & & & & & & \\
\hline & Average $(\%)$ & 17.0 & 18.3 & +0.72 & 23.1 & 24.5 & +0.62 \\
\hline & Median (\%) & 1.0 & 1.3 & +2.63 & 2.6 & 3.2 & +2.05 \\
\hline & Std. dev. & & & & 0.37 & 0.37 & \\
\hline
\end{tabular}

$\Delta 97-07$ corresponds to the annualized growth rate between 1997 and 2007 . This sample of firms produces mainly goods (i.e., whose service intensity is below $50 \%$ over the period) or mainly services. Servitized firms are firms reporting strictly positive sales of services. 


\subsection{Transition matrix}

Table 8 - Transition Matrix - Change in Service Intensity between 1997 and 2007

\begin{tabular}{l|cccccccccccc}
\hline from $\backslash$ to & $0 \%$ & bin1 & bin2 & bin3 & bin4 & bin5 & bin6 & bin7 & bin8 & bin9 & bin10 & $100 \%$ \\
\hline $0 \%$ & $\mathbf{1 1 . 9 8}$ & $\mathbf{7 . 4 2}$ & 0.40 & 0.17 & 0.11 & 0.06 & 0.05 & 0.05 & 0.05 & 0.04 & $\mathbf{0 . 2 5}$ & $\mathbf{1 . 3 0}$ \\
bin1 & $\mathbf{5 . 8 9}$ & $\mathbf{3 9 . 4 9}$ & 2.78 & 0.82 & 0.40 & 0.17 & 0.15 & 0.10 & 0.06 & 0.08 & $\mathbf{0 . 4 2}$ & $\mathbf{1 . 5 7}$ \\
bin2 & 0.23 & 1.79 & $\mathbf{1 . 1 7}$ & 0.47 & 0.18 & 0.12 & 0.05 & 0.04 & 0.01 & 0.04 & 0.03 & 0.24 \\
bin3 & 0.09 & 0.63 & 0.45 & $\mathbf{0 . 4 2}$ & 0.20 & 0.14 & 0.07 & 0.03 & 0.02 & 0.03 & 0.05 & 0.13 \\
bin4 & 0.04 & 0.26 & 0.13 & 0.21 & $\mathbf{0 . 1 9}$ & 0.12 & 0.11 & 0.07 & 0.02 & 0.01 & 0.05 & 0.13 \\
bin5 & 0.03 & 0.13 & 0.07 & 0.11 & 0.13 & $\mathbf{0 . 1 8}$ & 0.08 & 0.07 & 0.07 & 0.01 & 0.04 & 0.09 \\
bin6 & 0.01 & 0.11 & 0.03 & 0.06 & 0.05 & 0.11 & $\mathbf{0 . 1 2}$ & 0.08 & 0.04 & 0.04 & 0.07 & 0.08 \\
bin7 & 0.01 & 0.06 & 0.03 & 0.04 & 0.04 & 0.05 & 0.08 & $\mathbf{0 . 1 0}$ & 0.08 & 0.08 & 0.05 & 0.10 \\
bin8 & 0.02 & 0.08 & 0.01 & 0.02 & 0.03 & 0.03 & 0.04 & 0.05 & $\mathbf{0 . 1 2}$ & 0.09 & 0.12 & 0.16 \\
bin9 & 0.02 & 0.07 & 0.01 & 0.01 & 0.01 & 0.02 & 0.03 & 0.04 & 0.08 & $\mathbf{0 . 1 4}$ & 0.23 & 0.20 \\
bin10 & $\mathbf{0 . 0 8}$ & $\mathbf{0 . 3 1}$ & 0.06 & 0.02 & 0.02 & 0.03 & 0.03 & 0.05 & 0.08 & 0.13 & $\mathbf{2 . 3 6}$ & $\mathbf{1 . 9 6}$ \\
$100 \%$ & $\mathbf{0 . 8 3}$ & $\mathbf{1 . 3 8}$ & 0.22 & 0.18 & 0.12 & 0.12 & 0.14 & 0.13 & 0.13 & 0.15 & $\mathbf{1 . 6 3}$ & $\mathbf{3 . 8 1}$ \\
\hline
\end{tabular}

Notes: Constant sample of 29,909 firms. Lines refer to the service intensity in 1997, while columns refer to the service intensity in 2007 . Bins are defined as $10 \%$ intervals of service intensity. Firms in bin 5 have a service intensity between $40 \%$ and $50 \%$. The first and last columns $(0 \%$ and $100 \%)$ refer to firms that produced either only goods or only services, respectively, in 2007.

\subsection{Robustness checks}

Table 9 - Impact of Servitization on Firm Profitability - Alternative Controls and Estimators

\begin{tabular}{ccccccc}
\hline \hline & ATE & std. err. & \# Obs. & $\rho$ (p-value) & Method & Controls \\
\hline$(1)$ & $2.459^{a}$ & $(0.592)$ & 34,243 & $-0.158(0.001)$ & LDV-IV & $\Theta_{3}$ \\
$(2)$ & $1.693^{a}$ & $(0.165)$ & 34,243 & - & FE & $\Theta_{1}$ \\
$(3)$ & $4.585^{a}$ & $(0.669)$ & 34,243 & $-0.152(0.000)$ & FE -IV & $\Theta_{1}$ \\
$(4)$ & $4.597^{a}$ & $(0.665)$ & 34,243 & $-0.153(0.000)$ & FE-IV & $\Theta_{2}$ \\
\hline \hline
\end{tabular}

Notes: Stoppers and continuously servitized firms are excluded. Column (std. err.) reports the robust standard errors clustered by industry $\times$ year. Column (4) reports the value of $\rho$ and the corresponding P-value of the Wald test. P-values below $10 \%$ indicate that we can reject the null hypothesis of no correlation between the treatment errors and the outcome errors. Column (6) indicates the set of control variables: $\Theta_{1}=$ lagged employment level; $\Theta_{2}=\Theta_{1}$, lagged market share and interaction between lagged market share and lagged industry-level Herfindahl index; $\Theta_{3}=\Theta_{2}$, Profit ${ }_{i, t-1}$, Profit Prt $_{i-2}$ and Profit $_{i, t-3}$. Line (1) reports lagged dependent variable model estimates. Lines (2), (3) and (4) report firm-level fixed effects estimates. Lines (1), (3) and (4) report the full maximum likelihood estimates of the ATE, where the treatment variable, $\mathbb{1}\left(\operatorname{serv}_{i, t-1}\right)$, is instrumented by the (2-year lagged) distance-weighted sum of servitized producers in the corresponding industry. Line (2) reports the OLS estimates. All regressions include industry $\times$ year fixed effects. Significance levels: ${ }^{c}: p<0.1,{ }^{b}: p<0.05,{ }^{a}: p<0.01$. 
Table 10 - Impact of Servitization on Firm Profitability - Alternative Samples

\begin{tabular}{llllllll}
\hline \hline & ATE & std. err. & \# Obs. & $\rho$ (p-value) & \multicolumn{3}{c}{ Samples } \\
\cline { 5 - 7 } & & & & & $\begin{array}{c}\text { Starts } \\
\text { only }\end{array}$ & $\begin{array}{c}\text { With } \\
\text { stops }\end{array}$ & $\begin{array}{c}\text { All } \\
\text { years }\end{array}$ \\
\hline$(1)$ & $2.575^{a}$ & $(0.878)$ & 27,415 & $-0.123(0.018)$ & $\checkmark$ & & \\
$(2)$ & $2.953^{c}$ & $(1.834)$ & 72,034 & $-0.207(0.154)$ & & $\checkmark$ & \\
$(3)$ & $3.168^{a}$ & $(0.899)$ & 22,304 & $-0.213(0.003)$ & & & $\checkmark$ \\
$(4)$ & $3.457^{b}$ & $(1.375)$ & 17,300 & $-0.171(0.045)$ & $\checkmark$ & & $\checkmark$ \\
$(5)$ & $5.803^{a}$ & $(1.499)$ & 51,232 & $-0.421(0.000)$ & & $\checkmark$ & $\checkmark$ \\
\hline \hline
\end{tabular}

Notes: Lagged dependent variable model with 3 lags, controlling for lagged employment and industry $\times$ year fixed effects. All lines report estimates by full maximum likelihood, where the treatment variable, $\mathbb{1}\left(\operatorname{serv}_{i, t-1}\right)$, is instrumented by the (2-year lagged) distance-weighted sum of servitized producers in the corresponding industry. Column (std. err.) reports robust standard errors clustered by industry $\times$ year. Column (4) reports the value of $\rho$ and the corresponding P-value of the Wald test of the exogeneity of the instrumented variables. Line (1) uses the sample of firms that were not producing services at $t-2$. Line (2) includes all firms except those that always produce services. Line (3) replicates the benchmark regressions shown in column (6) of table 2 for the panel of firms active from 1997 to 2007. Lines (4) and (5) replicate the regressions shown in lines (1) and (2) for the panel of firms active from 1997 to 2007. Significance levels: ${ }^{c}: p<0.1,{ }^{b}: p<0.05,{ }^{a}: p<0.01$.

Table 11 - Impact of Servitization on Firm Employment, Turnover, and Production of Goods - Fixed Effects Estimates

\begin{tabular}{llcccc}
\hline \hline & Variable & ATE & std. err. & \# Obs. & $\rho$ (p-value) \\
\hline (1) & Employment & $0.068^{a}$ & $(0.032)$ & 34,243 & $0.026(0.7418)$ \\
$(2)$ & Turnover & $0.116^{a}$ & $(0.014)$ & 34,243 & $-0.093(0.000)$ \\
$(3)$ & Prod. goods & $0.087^{a}$ & $(0.014)$ & 34,243 & $-0.095(0.000)$ \\
\hline
\end{tabular}

Notes: Fixed effects model controlling for industry $\times$ year fixed effects in all regressions and for lagged employment in (2), (3), and (4). The treatment variable is instrumented by the (2-year lagged) distance-weighted sum of servitized producers in the corresponding industry and size decile. Estimator: two-step (line 1 ) and full maximum likelihood (lines 2 and 3). The (std. err.) column reports robust standard errors clustered by industry $\times$ year. The last column reports the value of $\rho$ and the corresponding $P$-value of the Wald test of the exogeneity of the instrumented variables. Significance levels: ${ }^{c}: \mathrm{p}<0.1,{ }^{b}: \mathrm{p}<0.05,{ }^{a}: \mathrm{p}<0.01$. 
Table 12 - Impact of Servitization by Sector - Micro and Small Businesses

\begin{tabular}{|c|c|c|c|c|}
\hline & ATE & std. err. & \# Obs. & $\rho$ (p-value) \\
\hline \multicolumn{5}{|c|}{ 1- Food, Beverage, Tobacco } \\
\hline Profitability & $4.879^{a}$ & $(0.437)$ & 9952 & $-0.375(0.000)$ \\
\hline Ln Employment & $0.156^{a}$ & $(0.028)$ & 9952 & $-0.337(0.000)$ \\
\hline Ln Turnover & $0.040^{a}$ & $(0.012)$ & 9952 & $-.101(0.001)$ \\
\hline Ln Prod. goods & $0.039^{a}$ & $(0.013)$ & 9952 & $-0.102(0.000)$ \\
\hline \multicolumn{5}{|c|}{ 2- Textile, Leather } \\
\hline Profitability & -0.920 & $(2.427)$ & 1105 & $0.141(0.848)$ \\
\hline Ln Employment & 0.118 & $(0.135)$ & 1105 & $-0.195(0.103)$ \\
\hline Ln Turnover & $0.234^{a}$ & $(0.064)$ & 1105 & $-0.382(0.001)$ \\
\hline Ln Prod. goods & $0.232^{a}$ & $(0.073)$ & 1105 & $-0.362(0.002)$ \\
\hline \multicolumn{5}{|c|}{ 3- Wood, Paper, Printing } \\
\hline Profitability & $6.889^{a}$ & $(1.970)$ & 4430 & $-0.458(0.004)$ \\
\hline Ln Employment & $0.265^{a}$ & $(0.054)$ & 4430 & $-0.576(0.000)$ \\
\hline Ln Turnover & $-0.363^{a}$ & $(0.033)$ & 4430 & $0.750(0.000)$ \\
\hline Ln Prod. goods & 0.037 & $(0.047)$ & 4430 & $-0.084(0.428)$ \\
\hline \multicolumn{5}{|c|}{ 4- Chemicals, Plastics } \\
\hline Profitability & $10.012^{a}$ & $(1.392)$ & 1187 & $-0.649(0.000)$ \\
\hline Ln Employment & 0.128 & $(0.129)$ & 1187 & $-0.240(0.501)$ \\
\hline Ln Turnover & $0.252^{b}$ & $(0.121)$ & 1187 & $-0.559(0.070)$ \\
\hline Ln Prod. goods & $0.233^{c}$ & $(0.131)$ & 1187 & $-0.517(0.114)$ \\
\hline \multicolumn{5}{|c|}{ 5- Mineral, Metal Products } \\
\hline Profitability & 3.334 & $(2.598)$ & 9216 & $-0.200(0.298)$ \\
\hline Ln Employment & $0.236^{a}$ & $(0.030)$ & 9216 & $-0.575(0.000)$ \\
\hline Ln Turnover & $0.065^{a}$ & $(0.009)$ & 9216 & $-0.120(0.000)$ \\
\hline Ln Prod. goods & $0.056^{a}$ & $(0.010)$ & 9216 & $-0.108(0.000)$ \\
\hline \multicolumn{5}{|c|}{ 6- Machinery, Electrical Equip. } \\
\hline Profitability & $2.759^{c}$ & $(1.545)$ & 3601 & $-0.120(0.249)$ \\
\hline Ln Employment & $0.151^{a}$ & $(0.042)$ & 3601 & $-0.358(0.000)$ \\
\hline Ln Turnover & 0.030 & $(0.023)$ & 3601 & $-0.054(0.122)$ \\
\hline Ln Prod. goods & 0.028 & $(0.022)$ & 3601 & $-0.059(0.060)$ \\
\hline \multicolumn{5}{|c|}{ 7- Manufacturing, n.e.c. } \\
\hline Profitability & $8.348^{a}$ & $(2.074)$ & 1671 & $-0.566(0.000)$ \\
\hline Ln Employment & $0.417^{a}$ & $(0.155)$ & 1671 & $-0.771(0.015)$ \\
\hline Ln Turnover & 0.118 & $(0.072)$ & 1671 & $-0.234(0.107)$ \\
\hline Ln Prod. goods & $0.124^{b}$ & $(0.061)$ & 1671 & $-0.257(0.031)$ \\
\hline
\end{tabular}

Notes: Lagged dependent variable model with 3 lags, controlling for lagged employment and industry $\times$ year fixed effects. All lines report estimates by full maximum likelihood (except for employment: two-step estimator), where the treatment variable, $\mathbb{1}\left(\operatorname{serv}_{i, t-1}\right)$, is instrumented by the (2-year lagged) distance-weighted sum of servitized producers in the corresponding industry and decile of size. Column (std. err.) reports robust standard errors clustered by industry $\times$ year. The last column reports the value of $\rho$ and the corresponding P-value of the Wald test of the exogeneity of the instrumented variables. Significance levels: ${ }^{c}: p<0.1,{ }^{b}: p<0.05,{ }^{a}: p<0.01$. 